\title{
Uganda: Third Review Under the Policy Support Instrument, Request for Waiver of Nonobservance of an Assessment Criterion, and Request for Modification of Assessment Criteria-Staff Report; Press Release on the Executive Board Discussion; and Statement by the Executive Director for Uganda.
}

In the context of the third review under the Policy Support Instrument, request for waiver of nonobservance of an assessment criterion, and request for modification of assessment criteria, the following documents have been released and are included in this package:

- $\quad$ The staff report for the third review under the Policy Support Instrument, request for waiver of nonobservance of an assessment criterion, and request for modification of assessment criteria, prepared by a staff team of the IMF, following discussions that ended on October 28, 2011, with the officials of Uganda on economic developments and policies. Based on information available at the time of these discussions, the staff report was completed on December 20, 2011. The views expressed in the staff report are those of the staff team and do not necessarily reflect the views of the Executive Board of the IMF.

- $\quad$ A Press Release summarizing the views of the Executive Board as expressed during its January 13, 2012 discussion of the staff report that completed the request and/or review.

- $\quad$ A statement by the Executive Director for Uganda.

The documents listed below have been or will be separately released.

Letter of Intent sent to the IMF by the authorities of Uganda*

Memorandum of Economic and Financial Policies by the authorities of Uganda*

Technical Memorandum of Understanding*

*Also included in Staff Report

The policy of publication of staff reports and other documents allows for the deletion of market-sensitive information.

Copies of this report are available to the public from

International Monetary Fund • Publication Services

$70019^{\text {th }}$ Street, N.W. • Washington, D.C. 20431

Telephone: (202) 623-7430 • Telefax: (202) 623-7201

E-mail: publications@imf.org Internet: http://www.imf.org

\section{International Monetary Fund Washington, D.C.}


INTERNATIONAL MONETARY FUND

UGANDA

\title{
Third Review Under the Policy Support Instrument, Request for Waiver of Nonobservance of an Assessment Criterion, and Request for Modification of Assessment Criteria
}

\author{
Prepared by the African Department \\ (In consultation with other departments) \\ Approved by Saul Lizondo and Dominique Desruelle
}

December 20, 2011

\begin{abstract}
Discussions: Held in Kampala during October 17-28, 2011. The mission met with Finance Minister Kiwanuka, Bank of Uganda Governor Tumusiime-Mutebile, Permanent Secretary/Secretary of Treasury Kassami, and other senior officials, as well as the media, representatives of parliament, the private sector, NGOs/CSOs, and development partners.
\end{abstract}

IMF team: T. Richardson (head, resident representative), L. Redifer, N. Ben Ltaifa, and N. Mireku (all AFR), P. Bartholomew (MCM), P. Wingender (FAD), and S. Wang (SPR). Ahmed Ndyeshobola (OED) and Rachel Sebudde (World Bank) participated in the discussions. The mission was supported by the staff of the Kampala office of the Fund, all of whom are seconded from the Bank of Uganda.

Fund relations: The 3-year PSI-supported program was approved by the Executive Board on May 12, 2010. The Board completed the second review under the PSI in June 2011, after having decided not to complete the first review in February 2011. The Executive Board concluded the 2010 Article IV consultations in February 2011.

Third Review under the PSI: All but one of the seven quantitative assessment criteria were met at end-June; most structural benchmarks were met, although several with a delay. Going forward, tighter monetary and fiscal policies in the near term aim to reduce inflation rapidly, while medium-term policies strive to create fiscal space to support stepped-up public infrastructure investment. Staff supports the authorities' request for a waiver of nonobservance of the quantitative assessment criterion, and proposes modified/new targets for end-December 2011 and end-June 2012, along with additional structural benchmarks aimed at controlling expenditure arrears and ensuring fiscal sustainability of the power sector. 


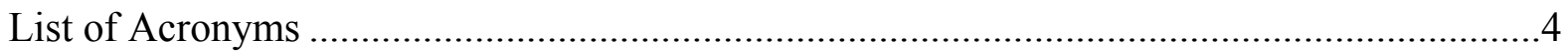

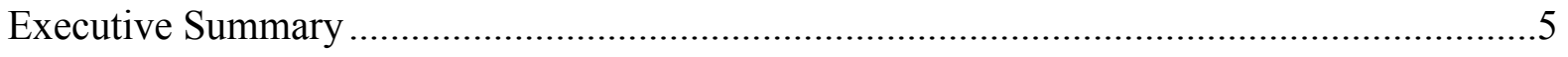

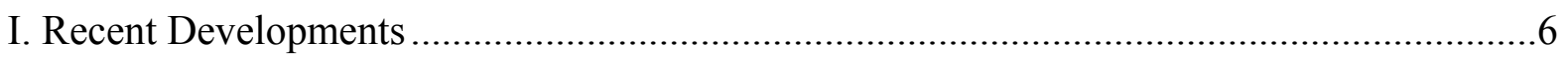

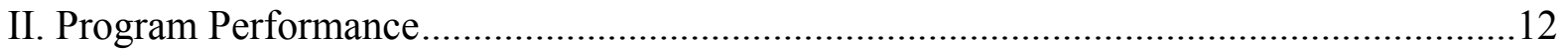

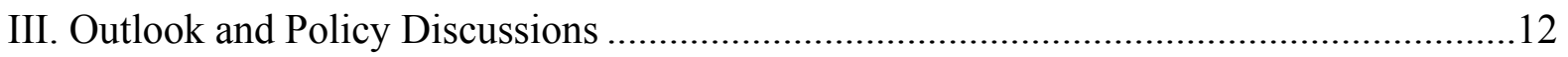

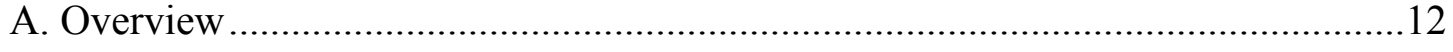

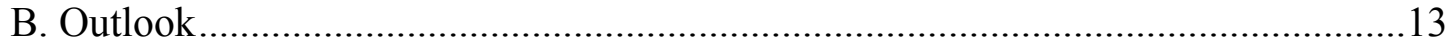

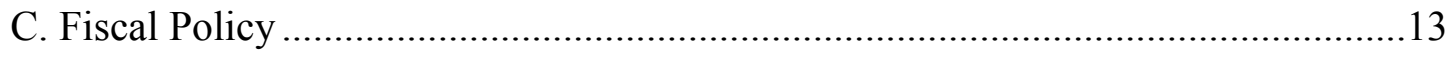

D. Monetary and Financial Sector Policies.......................................................... 16

E. External Sector and External Borrowing .......................................................... 18

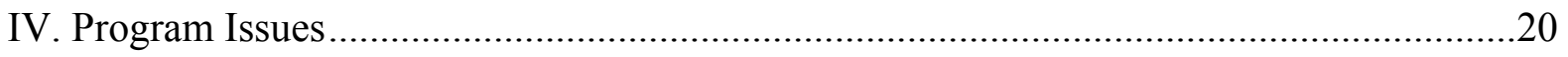

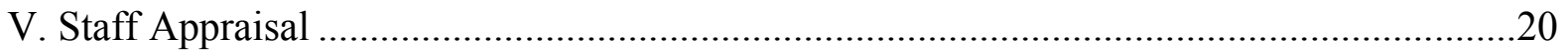

Boxes

1. Fiscal Policy Stance in Support of Disinflation............................................................14

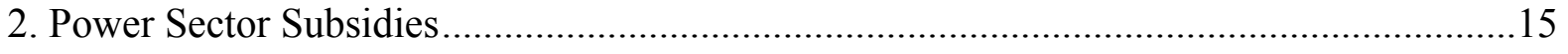

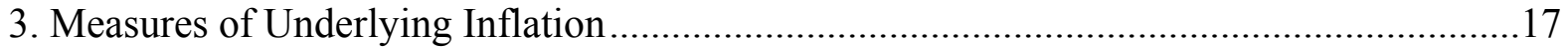

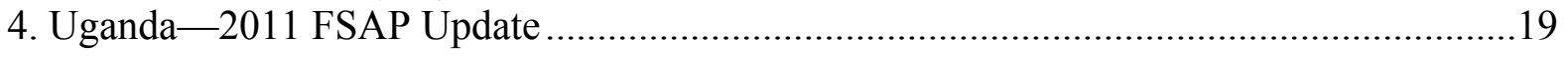

Figures

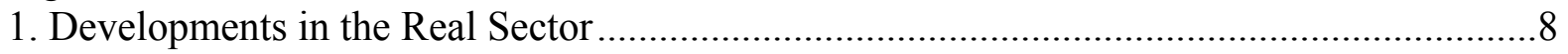

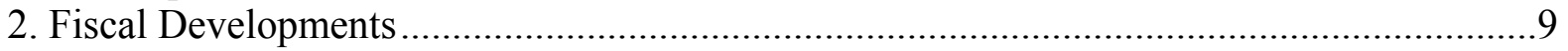

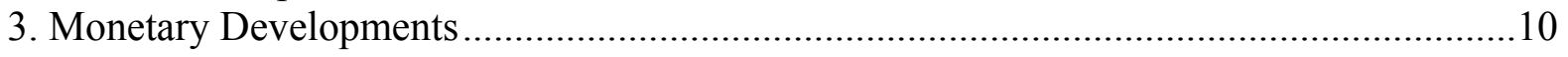

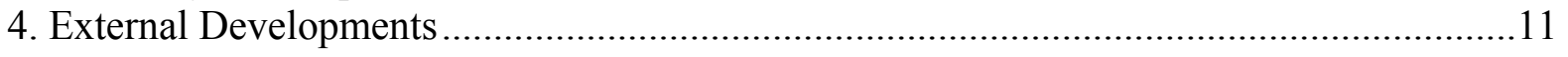

Tables

1. Selected Economic and Financial Indicators, FY2009/10-2014/15 ...............................22

2a. Fiscal Operations of the Central Government, FY2009/10-2014/15 .............................23

2b. Fiscal Operations of the Central Government, FY2009/10-2014/15 .............................24

2c. Quarterly Fiscal Operations of the Central Government, 2011/2012 .............................25

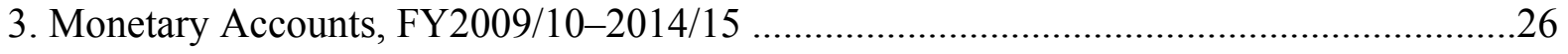

4. Balance of Payments, FY2009/10-2014/15 .............................................................27

5. Quantitative Assessment Criteria and Indicative Targets for June 30, 2011 ...................28

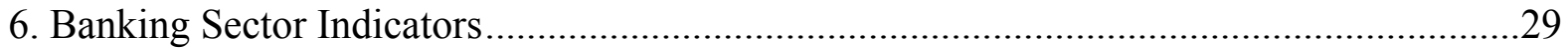

7. Structural Benchmarks Under the PSI ( $2^{\text {nd }}$ Review) Status of Implementation .................30 
Appendix

Letter of Intent

Attachments

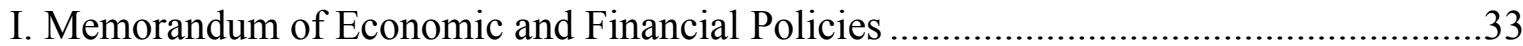

II. Technical Memorandum of Understanding .............................................................47 


\section{List of Acronyms}

\begin{tabular}{|c|c|}
\hline $\mathrm{BCP}$ & Basel Core Principles \\
\hline $\mathrm{BoU}$ & Bank of Uganda \\
\hline CBR & Central Bank Rate \\
\hline $\mathrm{CCS}$ & Commitment Control System \\
\hline CPI & Consumer Price Index \\
\hline $\mathrm{CSOs} / \mathrm{NGOs}$ & Civil Society Organizations/Non-Governmental Organizations \\
\hline EAC & East African Community \\
\hline EFU & Electricity, Fuel and Utilities \\
\hline ERA & Electricity Regulatory Authority \\
\hline FAD & IMF Fiscal Affairs Department \\
\hline FSAP & Financial Sector Assessment Program \\
\hline GDP & Gross Domestic Product \\
\hline HIPC & Highly Indebted Poor Country \\
\hline IT/ITL & Inflation Targeting/Inflation Targeting "Lite" \\
\hline $\mathrm{MCM}$ & IMF Monetary and Capital Markets Department \\
\hline MDAs & Ministries, Departments and Agencies \\
\hline MDRI & Multilateral Debt Relief Initiative \\
\hline MEFP & Memorandum of Economic and Financial Policies \\
\hline MoFPED & Ministry of Finance, Planning and Economic Development \\
\hline $\mathrm{NCB}$ & Non-concessional Borrowing \\
\hline NCG & Net Credit to Government \\
\hline NDA & Net Domestic Assets \\
\hline NDP & National Development Plan \\
\hline NFA & Net Foreign Assets \\
\hline NIR & Net International Reserves \\
\hline NPLs & Non-performing Loans \\
\hline OECD & Organization of Economic Cooperation and Development \\
\hline OED & IMF Office of Executive Director \\
\hline PAF & Poverty Alleviation Fund \\
\hline PAYE & Pay As You Earn \\
\hline PFA & Public Finance Act (draft) \\
\hline PFAA & Public Finance and Accountability Act (2003) \\
\hline PFM & Public Finance Management \\
\hline PRSC & World Bank Poverty Reduction Support Credit \\
\hline PRSP & Poverty Reduction Strategy Paper \\
\hline QAC & Quantitative Assessment Criterion \\
\hline STP & Straight-through Payment \\
\hline TMU & Technical Memorandum of Understanding (part of MEFP) \\
\hline UBOS & Uganda Bureau of Statistics \\
\hline $\mathrm{UCF}$ & Uganda Consolidated Fund \\
\hline URA & Uganda Revenue Authority \\
\hline VAT & Value Added Tax \\
\hline
\end{tabular}




\section{Executive Summary}

Uganda faces an increasingly challenging macroeconomic policy environment. Growth recovered in FY2010/11, but inflation has accelerated sharply and the nominal exchange rate depreciated by 20 percent against the US\$ from the beginning of 2011 to mid-August. Inflation was ignited by external developments, mainly a food price shock caused by drought in the Horn of Africa, but there is now clear evidence of second round inflationary momentum. At the same time, external balances have deteriorated and reserve coverage has dropped, while remaining above critical thresholds. Tight cash limits were only partly successful in containing fiscal spending pressures in FY2010/11, as net domestic financing was higher than expected and substantial arrears were accrued in the power sector.

Monetary policy has been tightened significantly to reduce core inflation, supported by a contractionary fiscal stance. The central bank policy interest rate has been increased four times in a row, by a total of 1000 basis points since July. The authorities have resisted domestic pressure this fiscal year to increase public sector wages as a result of high inflation, and they intend to maintain nominal spending broadly in line with the FY2011/12 budget, resulting in a large real spending contraction. The authorities recognize that disinflation policies will have an adverse impact on growth in the short run, but see disinflation as essential to protect longer term growth and poverty reduction. Additional current spending is accommodated in the program to meet power sector subsidies and prevent further arrears accumulation. A strategy will be developed to reduce power sector subsidies, including by gradually increasing user tariffs. An FSAP update found that the banking system is generally sound and well regulated, but regulatory frameworks for other financial services need improvement. Higher interest rates, lower growth and exchange rate volatility could put some pressure on banks' asset quality, but stress testing suggests a high degree of resilience.

Over the medium term, fiscal policy is focused on creating fiscal space to scale up public infrastructure investment in line with Uganda's National Development Plan. The authorities are implementing a number of measures to improve public financial management and to enhance revenue collection, both in preparation for oil production in a few years' time and to create room to spend and borrow for large priority infrastructure projects.

Six of seven quantitative assessment criteria (QACs) for end-June, 2011 were met, and most structural benchmarks were also met, although several with a delay. Net credit to government was missed by a significant margin (0.9 percent of GDP), due to underbudgeting for wages, road construction, and a higher than expected domestic interest bill. The authorities have agreed to a number of corrective actions to prevent similar spending overruns this fiscal year, including better intra-year monitoring of spending.

Staff supports the authorities' request to complete the third review, including a waiver of nonobservance of the ceiling on net credit to government, revision of the QACs for endDecember 2011, and new QACs for end-June 2012. The authorities have agreed to concrete policies to bring inflation down rapidly while putting fiscal policy on a sustainable medium term path aimed at achieving the program's core objectives to support sustained high growth and continued poverty reduction. 


\section{RECENT DEVELOPMENTS}

1. Uganda faces an increasingly challenging macroeconomic policy environment. High inflation, exchange rate depreciation, and power outages have led to protests and strikes. Policy credibility has been shaken in the past year by direct central bank lending to government for large military purchases, combined with uneven implementation of monetary policy and accrual of government spending arrears, particularly to power providers.

2. Inflation has continued to accelerate sharply. Both headline and core inflation reached an 18-year high in October, at 30.5 and 30.8 percent, respectively (y/y), the highest rates in the East African Community (EAC) (Figure 1). ${ }^{1}$ Sharp hikes in food prices, resulting especially from drought in the Horn of Africa, precipitated the increase. However, in recent months, abetted by continued strong domestic demand and pass through from sharp exchange rate depreciation in the first 9 months of 2011, non-food inflation has begun to catch up with food inflation (Box 3).

3. The shilling has stabilized since mid-August. ${ }^{2}$ It dropped 20 percent against the US\$ from January through mid-August, due to the factors outlined above, and then strengthened in October-November as the central bank increased interest rates. The real effective exchange rate remained relatively stable, declining by 0.9 percent since January 2011 (Figure 4).

4. Growth was stronger than expected in FY2010/11. ${ }^{3}$ At 6.7 percent $y / y$, growth was driven by industry and services, with lackluster agricultural performance (where over 70 percent of the labor force is engaged). Growth in credit to the private sector has remained strong (including in domestic currency terms), despite tightening of the monetary stance; however, services activity contracted in the last quarter. Services contribute over 50 percent to annual GDP, with industry and agriculture contributing about 25 percent and 14 percent, respectively (Figure 1).

\section{Despite tight cash limits which reined in spending in the second half of} FY2010/11, the end-June target for net credit to government was breached (by about 0.9 percent of GDP). Revenues increased as a share of GDP relative to FY2009/10. Higher election-related current spending was broadly offset by reductions in other spending, as had been agreed as a corrective measure in the context of the second program review. However, spending overruns in road construction, interest costs and the wage bill caused greater-than-

\footnotetext{
${ }^{1}$ November headline inflation was 29.0 percent and core inflation was 30.4 percent.

${ }^{2}$ Uganda's exchange rate arrangement is classified as de jure "free floating" and de facto "floating."

${ }^{3}$ Uganda's fiscal year covers July 1-June 30.
} 
anticipated domestic financing. In addition, payment arrears for power sector subsidies accrued in the amount of Ush 207 billion (about 0.5 percent of GDP). The bulk of the arrears (Ush 192 billion) were cleared in the first quarter of FY 2011/12, but continued payment delays have resulted in uneven provision of power, while also serving as a drag on growth.

\section{In early July, the BoU announced a revision to their monetary policy}

framework. Calling it "inflation targeting 'lite' (ITL)" in line with their medium-term objective of shifting to full-fledged IT, they introduced a benchmark central bank rate (CBR) with $\mathrm{a}+/-4$ percent point corridor, which targets the 7-day interbank interest rate. The BoU has retained its medium term core inflation target of 5 percent, but has not yet begun to publish a well-articulated intermediate inflation trajectory. (Program targets under the PSI-supported program continue to be based on monetary aggregates.) Indeed, staff noted that the new framework has introduced added transparency to the conduct of monetary policy, and thus is helping to strengthen the transmission channel from interest rates to domestic demand and inflation.

\section{The monetary policy stance has been tightened significantly in recent months,} but with limited impact on inflation so far. Reserve money growth decelerated to 24 percent $y / y$ in September (from above 38 percent in January). The CBR has been increased four times since it was introduced in July, including with aggressive increases in October and November, by 400 and 300 basis points, respectively. As of early-December, the CBR was 23 percent, with the upper range of the band at 27 percent. More aggressive tightening has provided support for the shilling and given a strong message to markets about the readiness of the central bank to combat inflation. Preliminary reports suggest that private sector credit growth began to decline rapidly in October and November.

8. External balances deteriorated in FY2010/11. The current account deficit (including grants) is estimated to have worsened to 12.9 percent of GDP from 9.6 percent in FY2009/10. The main factors were limited growth in exports due to weaker external demand, coupled with strong imports, both in volume and value terms, particularly for oil and construction services. International reserve coverage diminished to 3.3 months of imports by end-June (from 5.1 months in FY2008/09), largely as a function of large military purchases over the last two years and sales of foreign exchange to contain shilling volatility in the first nine months of 2011. In July, the government sold US\$450 million in foreign exchange (received from a capital tax payment for the sale of oil exploration licenses) to the central bank. This has boosted reserve coverage to around 3.5 months worth of future imports.

\section{BoU Gross Foreign Reserves}

In months of next fiscal year's imports of goods and services

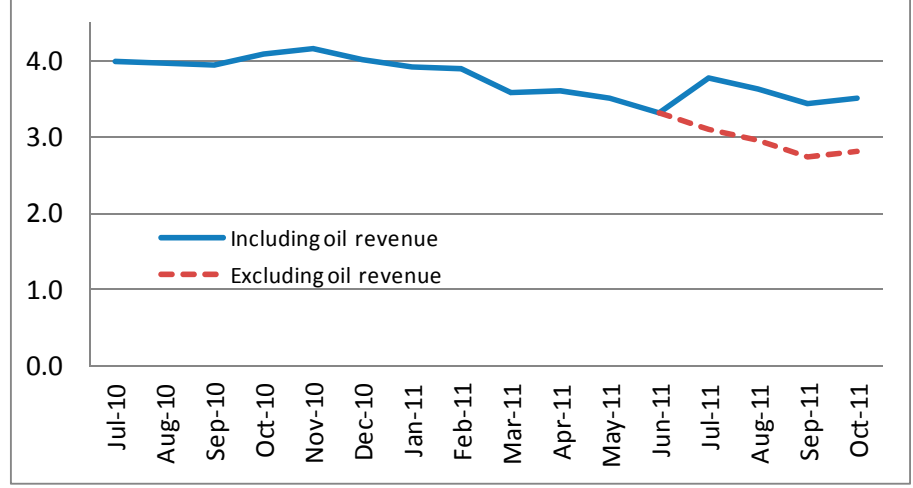


Figure 1. Developments in the Real Sector

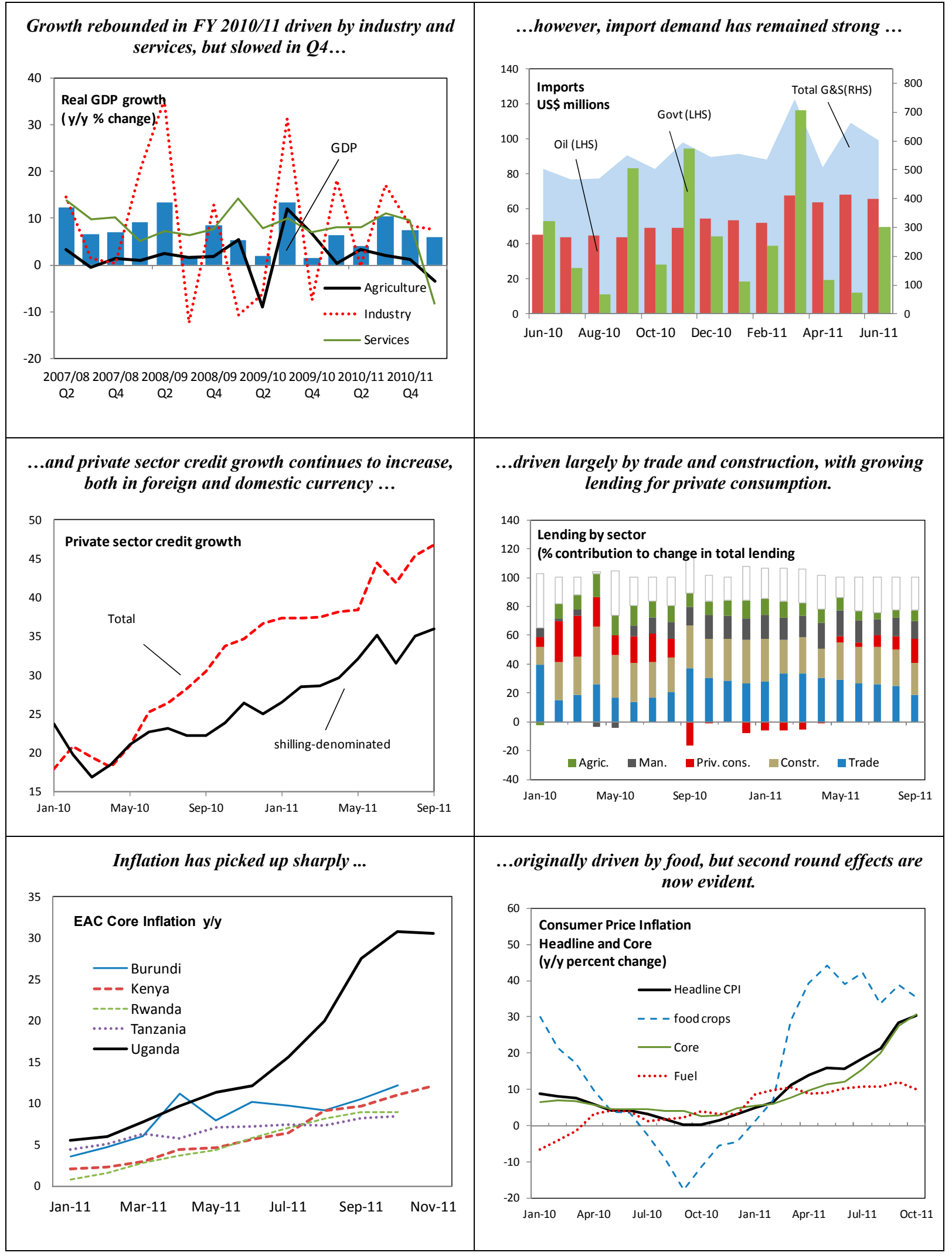




\section{Figure 2: Fiscal Developments}

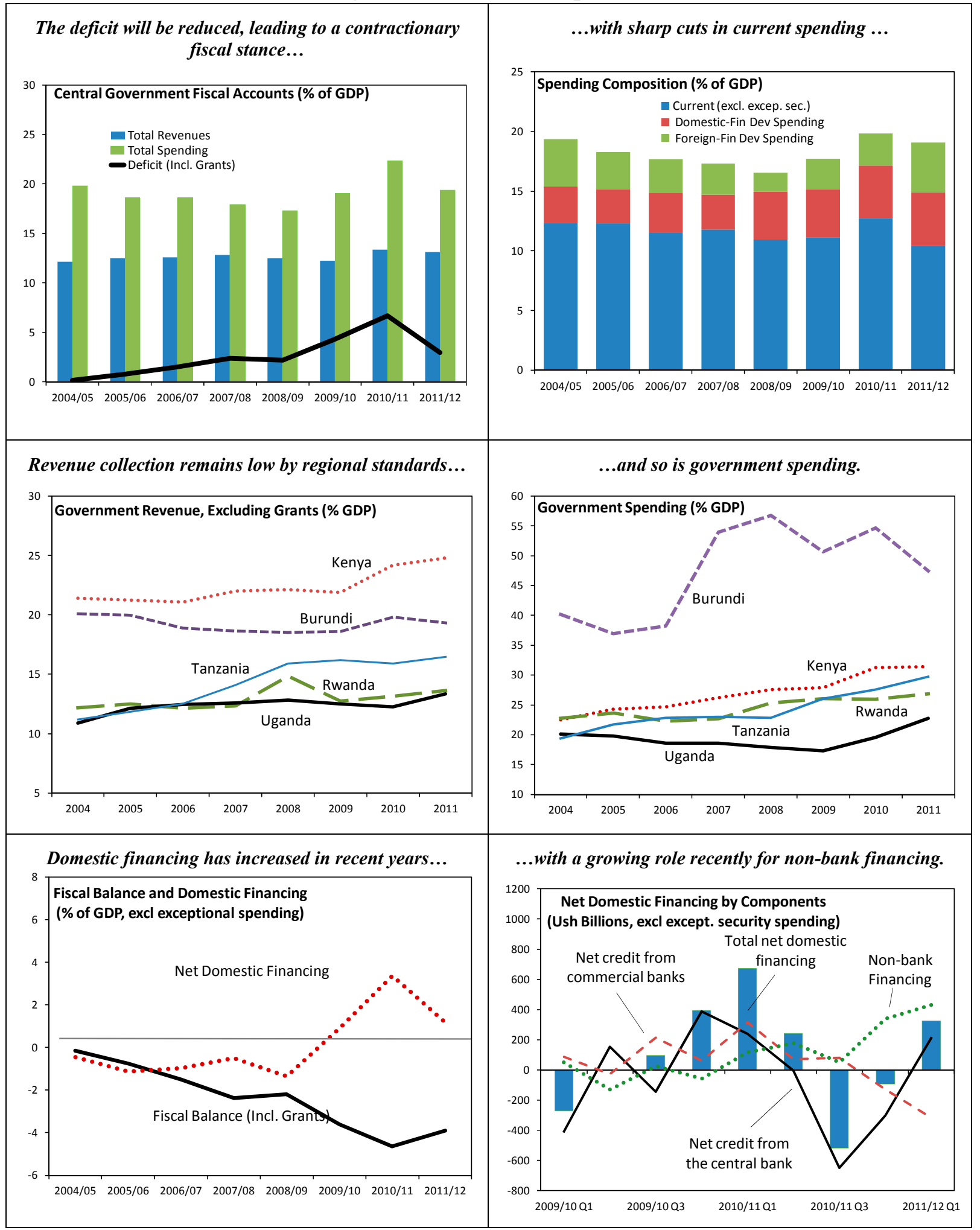




\section{Figure 3. Monetary Developments}

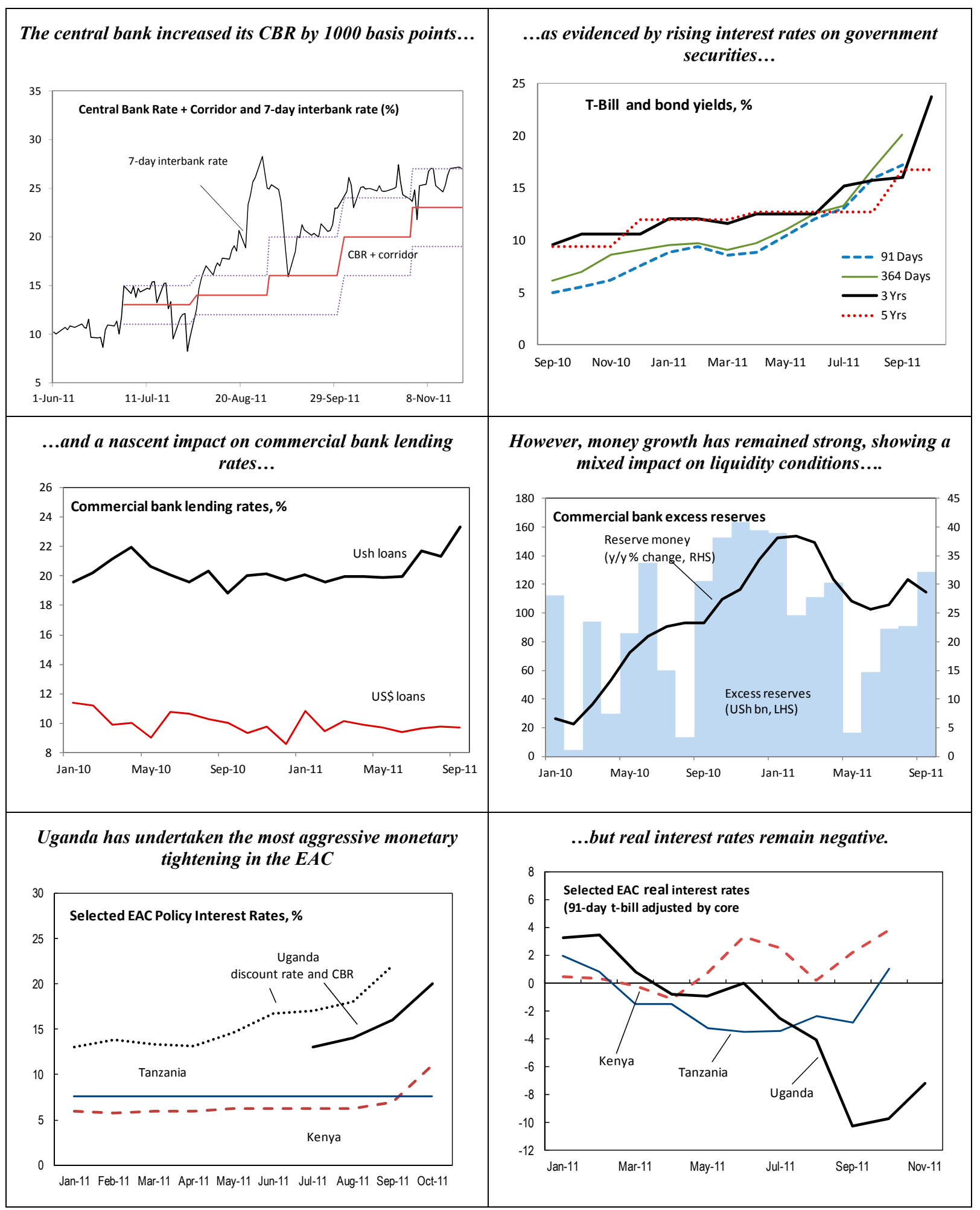




\section{Figure 4. External Developments}

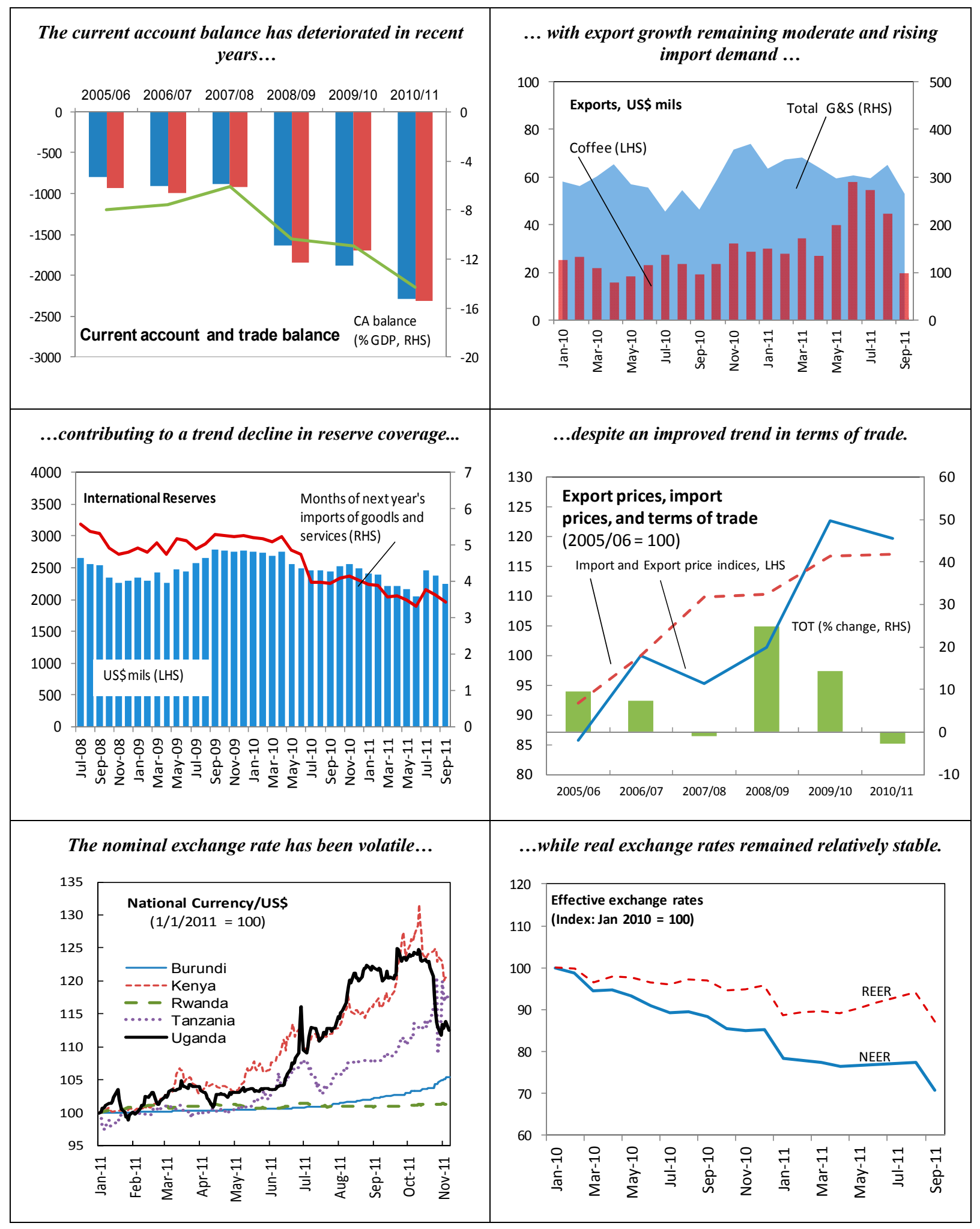




\section{Program Performance}

9. The Executive Board completed the second review under the PSI on June 29, 2011 after non-completion of the first review in February. Completion of the second review was based on a series of corrective measures to set fiscal policy on a more sustainable trajectory, including tax revenue enhancements.

\section{All end-June QACs were observed, except for net credit to government (NCG)} by the banking system. (Table 5). The NCG target was breached by 0.9 percent of GDP, largely due to higher wage and interest costs than foreseen in the budget and spending overruns in road construction. The authorities have agreed to new corrective actions for this fiscal year to ensure budget projections are more realistic and to better monitor spending overruns, as outlined in the next section. The indicative target on base money was observed. The indicative target on expenditures under the Poverty Action was missed by a negligible margin. The indicative target on domestic budgetary arrears under the Commitment Control System could not be assessed due to statutory delays in production of audited arrears figures. (Nevertheless, government has acknowledged that arrears of more than 0.5 percent of GDP were incurred for the power sector.). Going forward, monitoring of this quantitative indicative target will be supplemented by the structural benchmark to monitor unpaid payment claims to facilitate timely monitoring (MEFP $₫ 5$ and $₫ 34$ ).

11. Most structural benchmarks were met, but several with a delay (Table 7 and MEFP -5). FY2011/12 tax measures outlined in the second PSI review have all been or are in the process of being implemented (See $\$ 19$ of Country Report No. 11/308 and MEFP |24), but it is too early to assess their impact. The measure to extend "straight through payments" to utility bills was not met, due to implementation problems as a result of the government's decentralized PFM accountability structure. It will be replaced with a new measure to publish quarterly releases, invoices and payments by ministry and responsible accounting officer, with resulting sanctions for arrears (MEFP, $\mid 5$ and $\mid 33$ ).

\section{Outlook And Policy Discussions}

\section{A. Overview}

\section{Policy discussions centered on ensuring that both monetary and fiscal policy} decisively support disinflation in order to safeguard medium-term growth and poverty reduction. As noted in AFR's Fall 2011 Regional Economic Outlook, Uganda has had a decade and a half of exceptionally strong and inclusive growth that has clearly reduced poverty and improved living standards. The performance was the legacy of a long track record of sound macroeconomic policies that created a stable platform for growth. The current challenging circumstances, which arose as a result of both external factors and internal policy decisions, call for clear action to restore macroeconomic stability. The authorities acknowledge there will be short term costs to the adjustment effort, but they see 
these as necessary to contain the larger costs in the long term, both to growth and to poverty reduction, of an extended period of very high inflation.

\section{B. Outlook}

13. The remainder of the fiscal year will be characterized by disinflation plus slower growth. Inflation is expected to abate during the first half of 2012, with core inflation likely to fall by about 10-12 percentage points by June, as the tighter monetary stance takes effect and remaining pass through of exchange rate depreciation fades. (Staff analysis suggests that the nominal exchange rate depreciation may take 3-6 months to pass through fully and could have been responsible for roughly one-third of the increase in inflation through October.) Growth is expected to decline, partly due to tighter monetary and fiscal policies, but also as a result of power outages and the weaker global outlook.

\section{The external current account deficit is expected to remain high over the medium} term, due mainly to large-scale infrastructure investment. The government's

development program focuses on import-intensive large infrastructure investment, including the large Karuma hydro-power plant and a few major road projects. The forecast assumes some upfront spending on Karuma in FY2011/12, US\$150 million, with the bulk of the investment taking place in the subsequent two fiscal years. The projections also include imports to support infrastructure development for the oil sector. In the lead-up to oil production, it is expected that the current account deficit will widen until oil revenues begin to flow.

\section{Fiscal Policy}

\section{Fiscal policy for the remainder of FY2011/12 is designed to support disinflation}

efforts. Despite a somewhat higher nominal revenue forecast than when the budget was drawn up, the authorities wish to hold nominal spending as close as possible to the original budget envelope, bringing the overall deficit (including grants) down to 3.8 percent of GDP this fiscal year, compared to 7.2 percent in FY2010/11. (The comparable figures, excluding exceptional security spending, are 3.2 and 4.7 percent of GDP, respectively.) This reflects a reduction in current spending by 4.2 percentage points of GDP (excluding exceptional security spending, the reduction is by 2.3 percentage points of GDP). The reduction in current spending is offset slightly by an increase in development spending by 0.8 percentage points of GDP. In all, this adjustment implies a contractionary fiscal impulse (Box 1, MEFP $\mid 23){ }^{4}$

\footnotetext{
${ }^{4}$ The projected deficit is also lower than the forecast of 5.0 percent of GDP at the time of the second PSI review, reflecting reduced development spending, as the large Karuma hydropower project will get under way later than expected.
} 


\section{Revenue projections for FY2011/12 are cautious, given a soft first quarter} outcome and strong downside risks to growth. Based on the Q1 revenue outcome (14 percent higher in nominal terms than Q1 last year, or approximately half the inflation rate), agreed revenue projections are conservative, resulting in a slight decline in GDP terms, from 12.7 percent in FY2010/11 to 12.5 percent this year. The measures introduced in the FY2011/12 budget will likely mitigate some of the decline, but, as in FY2008/09, tax buoyancy will probably be affected by the slowdown in economic activity, compounded by the fact that the risks to growth are on the downside. The authorities have agreed that any additional domestic revenues (beyond those programmed) realized as a result of higher inflation will be saved in order to maintain the tight fiscal stance (MEFP q22). Looking to the future, the authorities restated their commitment to proposing elimination of a number of tax exemptions in the context of the FY2012/13 Budget (MEFP $q 24$ ).

\section{Box 1. Fiscal Policy Stance in Support of Disinflation}

In view of inflation developments, the authorities have decided to maintain a low fiscal deficit despite pressure to increase spending. The targeted primary balance for FY2011/12 is 1.9 percent of GDP, reflecting a contraction of 1.7 percentage points of GDP compared to FY2010/11. Taking into account that a shortfall of growth from potential should worsen the fiscal balance, on a cyclicallyadjusted basis, the target balance reflects a contractionary impulse of 2.1 percentage points of GDP.

Uganda: Fiscal Impulse of the Central Government, FY2009/10-2011/12

\begin{tabular}{|c|c|c|c|}
\hline & $2009 / 10$ & $2010 / 11$ & $\begin{array}{c}\text { 2011/12 } \\
\text { Proj. }\end{array}$ \\
\hline Overall fiscal balance (incl. grants) ${ }^{1}$ & -3.6 & -4.7 & -3.2 \\
\hline Primary balance & -2.5 & -3.6 & -1.9 \\
\hline Fiscal impulse (unadjusted for cyclical position) ${ }^{2}$ & 1.3 & 1.1 & -1.7 \\
\hline Fiscal impulse adjusted for cyclical position ${ }^{3}$ & 1.1 & 1.0 & -2.1 \\
\hline Output gap & -1.1 & -0.3 & -2.0 \\
\hline \multicolumn{4}{|c|}{$\begin{array}{l}{ }^{1} \text { Excluding exceptional security spending. } \\
{ }^{2} \text { The impulse is calculated as the change in the primary balance from the preceding year; }(-)= \\
{ }^{3} \text { The fiscal impulse adjusted for the fiscal impact of the deviation of growth from its potential; } \\
\text { the calculation assumes an elasticity of } 0.2 \text { and a potential GDP growth of } 7 \text { percent. }\end{array}$} \\
\hline
\end{tabular}

17. The authorities and the mission agreed that a supplementary budget allocation would be needed to ensure full coverage of power sector subsidy costs. The FY2011/12 budget did not allocate sufficient resources to cover growing power sector costs - both to meet the arrears carried over from FY2010/11 and expected ongoing subsidy expenditures. The authorities agree that additional budget authorizations will be needed to cover the estimated higher costs and avoid the emergence of any further arrears, even after near-term measures to contain costs, including an expected increase in tariffs early in 2012 (Box 2, MEFP q35). They also agreed that a strategy would be submitted to Cabinet early in 2012 to 
set power sector financing on a more sustainable basis over the medium term (MEFP $\{36$ ). The strategy should depoliticize power sector tariffs setting, while aiming at full cost recovery, with an automatic adjustment formula reflecting fuel price and exchange rate developments. It will also look at the medium term fiscal implications of power supply in light of strongly growing demand.

\section{Box 2. Power Sector Subsidies}

Power sector tariffs have not been increased since November 2006. The real value of power sector tariffs has fallen by half since then, with large industrial tariffs about $1 / 3$ lower than average.

In FY2010/11, the original budget allocation for power subsidies was doubled mid-year due to exchange rate depreciation and rising fuel prices. Despite this, the fiscal year ended with Ush 207 billion in arrears, most of which were cleared in Q1 FY 2011/12.

Given the need to clear arrears and cover growing costs, FY2011/12 approved budget allocation was increased to Ush 417 billion, leaving Ush 210 billion to meet current year costs. The authorities are taking measures to contain near term costs: the new hydropower plant on the Nile at Bujagali is about to come on line, allowing expensive thermal plants to be phased out, and a tariff increase. Load-shedding (power rationing) is taking up the slack. However, even with these measures, current year subsidy costs are likely to reach Ush 413 billion. As for the tariff increase, the regulatory authority has proposed a weighted average increase of 35 percent in the first quarter of 2012, which staff estimates is consistent with the subsidy costs included in the program. Government expects to bring a supplementary budget to parliament in April 2012 to cover the remaining approximately Ush 200 billion in costs.

Power subsidy requirements are expected to decline sharply in FY2012/13 as a result of the Bujagali hydropower plant. But they could go up again in $2014 / 15$ as demand growth once again outstrips supply.

Government's medium-term strategy (MEFP q36) is meant to clarify options to address the projected shortfall.

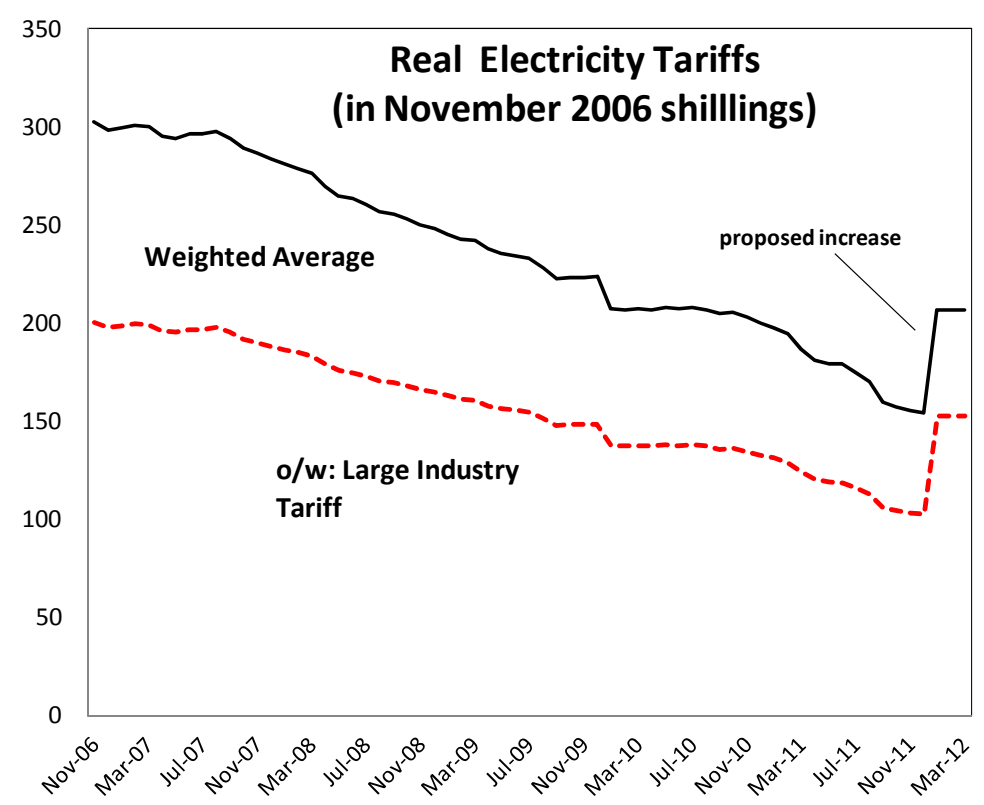

18. Over the medium term, fiscal policy aims to increase fiscal space for large-scale infrastructure investment (MEFP |27). The authorities have outlined planned revenue policy measures to include in the FY2012/13 budget, including elimination of a number of VAT exemptions for intermediate products. A few hard-hitting reforms to improve tax 
compliance have already been introduced this fiscal year. In particular, the Uganda Revenue Authority has begun to block large property transactions unless the purchaser can demonstrate that taxes were paid on the income used to effect payment. The FY2012/13 measures, combined with the full impact of FY2011/12 measures, are estimated to support an increase in revenues of 0.5 percentage points of GDP next year, with further measures to support similar increases over the medium term. In addition, to make the VAT work more efficiently, the authorities also intend, in the context of the FY2012/13 budget, to issuing VAT refunds directly rather than via budget appropriations.

19. Staff welcomed the authorities' plans to modernize their organic budget law. To improve budget preparation and execution, the authorities intend to submit to Parliament a wholesale revision of the Public Financial Accountability Act (PFAA) of 2003 by the end of this fiscal year (MEFP $\mid 31$ ). The new Public Finance Act (PFA) will encompass: a new budgetary calendar to accelerate and enhance the realism of budget preparation; stricter rules on supplementary spending appropriations; greater transparency about intra-year budgetary reallocation; and better accounting/audits. It is also expected to encompass the institutional framework for oil revenue management, which will emphasize transparency and preservation of the integrity of the budget system (MEFP $\$$ q137-38).

\section{Monetary and Financial Sector Policies}

20. The authorities and the mission agreed that the monetary policy stance needed to be tightened further to stem domestic inflation momentum. In spite of political and financial sector pressure to hold interest rates down, the central bank agreed that continued decisive efforts would be needed to reduce inflation, given widespread evidence that underlying inflation had begun to accelerate (Box 3). ${ }^{5}$ The BoU also emphasized that monetary policy is not being constrained by concerns about potential deterioration in financial sector asset quality. The program targets a reduction in core inflation from about 30 percent currently to 20 percent by June 2012, and to 10 percent by December 2012 (MEFP 118 ). This is to be achieved by reducing base money growth for the year to just under 16 percent (compared to nominal GDP growth of almost twice that amount), and maintaining the CBR at a level to stem credit growth and domestic demand (MEFP \19). Since October, the more aggressive tightening of the policy stance has resulted in a sharp appreciation of the exchange rate, and preliminary reports suggest that private sector credit growth is decelerating rapidly. November inflation was flat and real interest rates have become less negative. Going forward, the authorities will monitor demand indicators carefully to assess whether further tightening of the stance is needed (MEFP \19).

\footnotetext{
${ }^{5}$ Immediately following the mission, October inflations results became available and the BoU hiked the CBR by 300 basis points.
} 


\section{Box 3. Measures of Underlying Inflation}

Monetary policy in Uganda is based on core inflation - however, because its definition includes some food products (mainly processed food, e.g. maize flour, millet flour, fish, sugar, rice, oils and fats and tea, some imported), as such, it does not correct fully for the effects of the food price shock in measuring underlying inflationary pressure. The Uganda Bureau of Statistics (UBOS) produces other analytical presentations, including food vs. non-food.

- Core vs. noncore: Core inflation comprises 81.6 percent of the CPI basket, while noncore includes EFU (electricity, fuel, utilities), equal to 4.9 percent, and "food crops" (non-processed food deemed as traded goods) at 13.5 percent.

- Food vs. nonfood: Food (including the portion in core) makes up 27.2 percent, while nonfood is 72.8 percent.
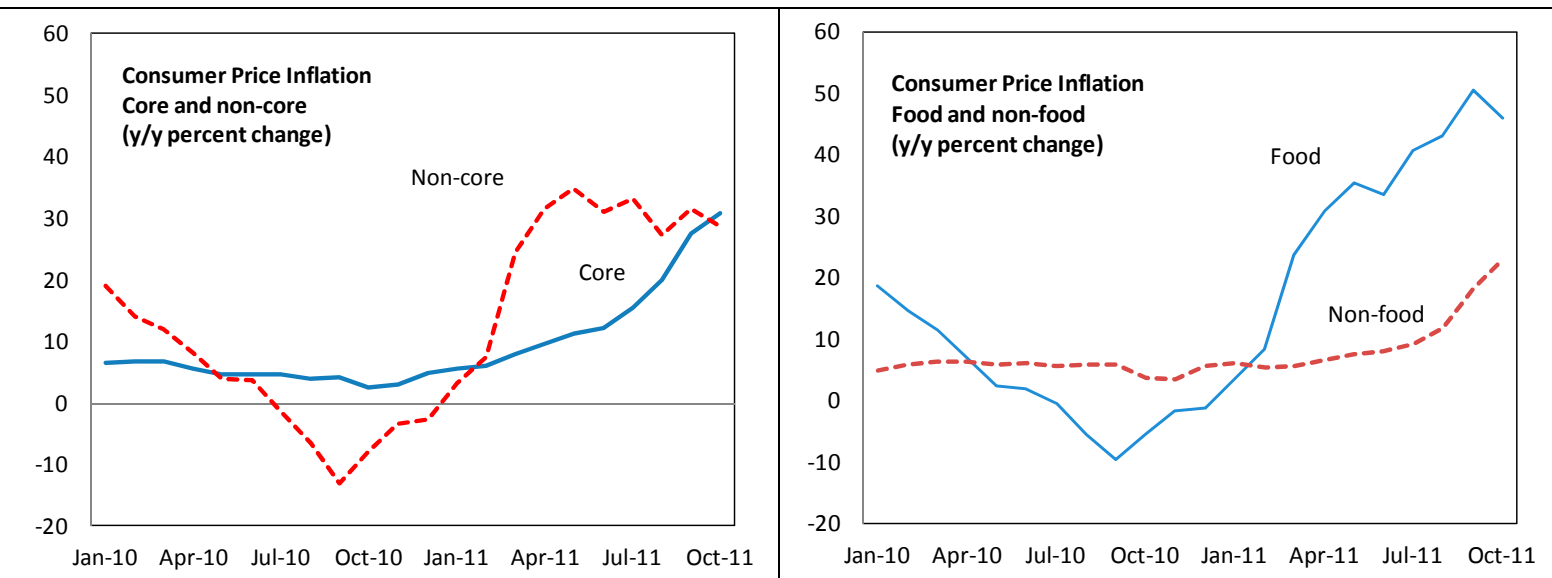

Both core and nonfood show a rising trend in recent months. To confirm the trends, staff disaggregated the CPI series to construct several alternative measures, each of which pointed to a strong upward trend, particularly pronounced since August. Looking to the future, it is expected that improved measures of underlying inflation could be developed in the context of statistical harmonization in the EAC.

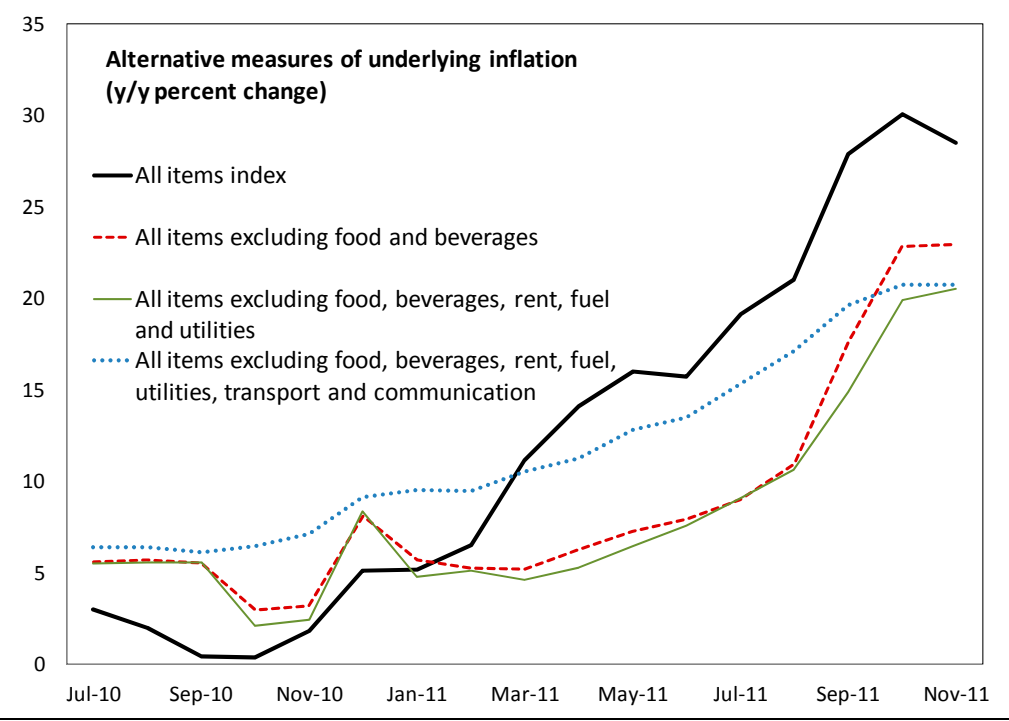


21. The authorities and the mission discussed the option of modifying the PSI program monitoring framework to specify an inflation consultation arrangement rather than a target for base money. While recognizing that the BoU's newly-introduced ITL framework has enhanced the transparency and effectiveness of monetary policy, staff argued that it would be premature to change program monitoring at this time, given that a full-fledged IT framework is not yet in place. The mission noted that program monitoring frameworks in other inflation targeting countries have been adjusted only after those countries have moved to full-fledged IT, following several years of analysis of the transmission mechanism.

22. The mission urged the authorities to strengthen banking system supervision in light of much higher interest rates. An FSAP update was conducted in August 2011: stress tests indicate that the Ugandan banking system should be resilient to significant shocks (Box 4, Table 6). Nevertheless, given the very rapid tightening in credit conditions coupled with exchange rate volatility, the mission emphasized the need for the $\mathrm{BoU}$ to remain vigilant in monitoring bank balance sheets, while also being mindful of potential volatility stemming from cross-border flows. Moreover, in line with the FSAP recommendations, the mission encouraged the BoU to strengthen the framework for off-site supervision and underscored the need for the BoU to enhance its liquidity management framework (including prudent and more flexible use of its standing facilities) to help address any liquidity shortages of individual banks.

\section{E. External Sector and External Borrowing}

\section{In light of the balance of payments forecast, there was agreement that} international reserves would need to be carefully guarded. The tight monetary policy stance will help to safeguard reserves while withstanding downward pressure on the shilling. The forecast shows reserves staying above 3 months' worth of future goods and services imports, with a modest increase over the medium term (MEFP $\mid 17$ ). This forecast assumes a fairly steady increase in foreign direct investment to support the development of the oil sector, but modest financial sector inflows otherwise.

\section{Recognizing that traditional financing will be insufficient to implement a bold} investment agenda, the authorities are considering a variety of financing options for infrastructure scaling-up (MEFP q28). Domestic financing, for example an infrastructure bond following Kenya's example, is an option, but would not necessarily generate adequate foreign exchange for import-intensive infrastructure projects. For the time being, the authorities are just studying the possibility of an infrastructure bond, so it is not accommodated in the PSI-supported program at this review. Expanded external financing on commercial terms is also being examined, though the authorities' immediate objective is to improve their credit rating. In preparation, the authorities will update their 2007 mediumterm Debt Management Strategy by the end of the fiscal year, and are seeking IMF technical assistance in this regard (MEFP \$39). 


\section{Box 4. Uganda: 2011 FSAP Update}

\section{The FSAP Update found that Uganda has made progress in modernizing and} expanding its financial sector. Bank credit has grown rapidly and nonperforming loans remain quite low. Competition has increased and the banking sector remains reasonably wellprovisioned. However, one third of the banks — chiefly small — have been unprofitable for two years. Despite enhanced financial depth and competition, efficiency gains associated with greater competition in the banking sector (tighter spreads between lending and deposit rates) have yet to materialize; capital markets remain underdeveloped; and crisis management expertise remains confined to the central bank.

High inflation poses a major challenge to the banking sector. While banks appear wellpositioned to cope with rising inflation, the increase in bank lending rates raises serious concerns about bank customers' ability to service their debt. It is unclear how long the banks could sustain credit losses if inflation, high interest rates, and foreign exchange vulnerabilities were to continue for a significant period.

While the central bank has made progress in implementing risk-based supervision, the Basel Core Principles (BCP) assessment shows room for improvement. In particular, work remains to be done to ensure that the regulatory environment keeps pace with innovation and growth in the financial sector. The authorities need to address legislative and regulatory gaps, including with respect to oversight of emerging products and services. A large and growing number of nonbank financial institutions (mainly credit cooperatives) have expanded financial services in rural areas, but are not regulated. The spread of mobile payments and its growing integration with the more formal retail payments and bank systems bodes well for further expansion and inclusion, but poses some challenges to payment system stability.

Finally, longer term finance remains elusive, constraining development in several sectors. Nascent reform of the pension sector should be accelerated, and the regulatory framework for insurance and capital markets strengthened, while still facilitating further expansion. Reforms are needed to: (i) strengthen bank licensing; (ii) enhance cross-border collaboration; (iii) improve liquidity and crisis management; (iv) strengthen nonbank financial supervision; and (v) adopt a national payments systems law, encompassing mobile services.

25. The authorities do not anticipate further requests to increase the program's nonconcessional borrowing ceiling this fiscal year (MEFP q28). Any commercial external borrowing would take place within the existing ceiling (which has remaining headroom of US\$300 million), and be consistent with the stipulation that it be used to finance infrastructure investment. Despite the space, the authorities have expressed their preference to borrow only once projects are "shovel-ready." 


\section{Program Issues}

26. The authorities have requested a waiver for the nonobservance of the quantitative assessment criterion for net credit to government by the banking system. They acknowledge that the breach was due to poor budgetary planning and a lack of monitoring of spending overruns (MEFP $q 4$ ). They have agreed on a set of corrective actions to: develop a strategy to set power sector financing on a more sustainable basis, with immediate actions to avoid further accrual of arrears this year; strengthen monitoring of unpaid spending claims to prevent general arrears accumulation; outline specific new revenue measures that will be included in the FY2012/13 budget to expand domestic resources; and submit the new draft PFA to parliament this fiscal year.

\section{Revised QACs for end-December 2011 and end-June 2012 (test dates for the} fourth and fifth reviews under the PSI), and supportive structural measures, are presented in the authorities' MEFP (Attachment I to the Minister's Letter of Intent). The revised QACs are more ambitious than those presented in at the time of the second review, reflecting tightening of fiscal and monetary policy. The authorities are also working on a progress report on implementation of the National Development Plan, which is expected to be submitted at the time of the fourth review of the program.

28. Nevertheless, there are risks to the program, including that: growth could fall below projections as a result of a higher-than-anticipated impact of tighter fiscal and monetary policies and a worsening global outlook; inflationary momentum may be difficult to reverse; the tight fiscal stance could prove too hard to implement in light of domestic pressure and protests; volatile exchange rate movements could resume, putting pressure on international reserves and inflation; and external sector developments could be worse than projected, putting pressure on reserves. Finally, there is some risk that it may be difficult to increase electricity tariffs to contain power sector subsidies, thus requiring more spending.

\section{Staff Appraisal}

29. The tighter monetary policy stance of the Bank of Uganda is welcome. Staff encourages the authorities to maintain the tight stance of monetary policy for as long as needed to reverse inflationary expectations and reduce inflation as envisaged under the program.

30. The budgetary stance for FY 2011/12 must also remain tight to support the disinflation efforts of the BoU. Slower GDP growth may affect revenue performance, underscoring the need for enhanced budgetary discipline. The arrears incurred at the end of FY 2010/11 along with the extra spending which led to the need for a program waiver, are emblematic of underlying problems with budget preparation and implementation.

Strengthening commitment controls can help, but will not prevent accumulation of arrears if the budget is not realistic. At the same time, spending units must face effective sanctions for making spending commitments beyond levels authorized. In this regard, staff welcomes the 
submission to Cabinet of the draft Public Finance Act, which will improve the basic PFM framework while also establishing an oil revenue management system.

\section{Over the medium term, fiscal adjustment should include both revenue} enhancement and more spending discipline, including a gradual phasing out of subsidies for power sector tariffs. Uganda's revenue performance remains the weakest in the EAC, and its power sector tariffs have not been increased since 2006. The FY2012/13 Budget will be an opportunity for Uganda to make a significant break with the past by closing a number of tax loopholes and exemptions. Staff welcomes the authorities' plans to raise power sector tariffs in early 2012, but notes that medium-term fiscal sustainability also depends on an apolitical tariff-setting mechanism aimed at full cost recovery, whereby electricity tariffs adjust automatically with changes in underlying costs.

32. The infrastructure gap remains Uganda's key bottleneck to growth. The timing of implementation of flagship projects in the National Development Plan (such as roads, rail, a refinery, and power projects) will depend at least as much on the preparedness of Ugandan planners as it will on the availability of financing. Staff agrees that a deep inventory of wellengineered, vetted, and appraised projects that are "shovel ready" and widely-agreed must be established before scaling up borrowing, to avoid carrying costs and the risk that funds raised for investment might be diverted to current spending.

33. Uganda's financial sector, while judged as sound by the recent FSAP, must cope with a period of tighter monetary policy. Exchange rate volatility coupled with slower growth and much higher interest rates could put some pressure on asset quality, although FSAP stress testing indicates a high degree of resilience. Staff urges the authorities to remain vigilant and rely on the mechanisms and tools they have to manage these issues. It encourages the authorities to monitor the situation closely, including to identify potential risks from cross-border flows in the current global environment.

34. Based on the strength of current and envisaged macroeconomic policies, including corrective actions taken to address previous slippages, staff supports completion of the third review. It recommends modification of QACs for end-December 2011, and a waiver of nonobservance for the missed QAC on NCG at end-June 2011, on the basis of the strong actions government is taking to rein in spending during the current fiscal year and improve public financial management through a comprehensive new law. Staff also supports the authorities' proposed new structural benchmarks, which aim to enhance spending controls to prevent accumulation of arrears. 
Table 1. Uganda: Selected Economic and Financial Indicators, FY2009/10-2014/15 ${ }^{1}$

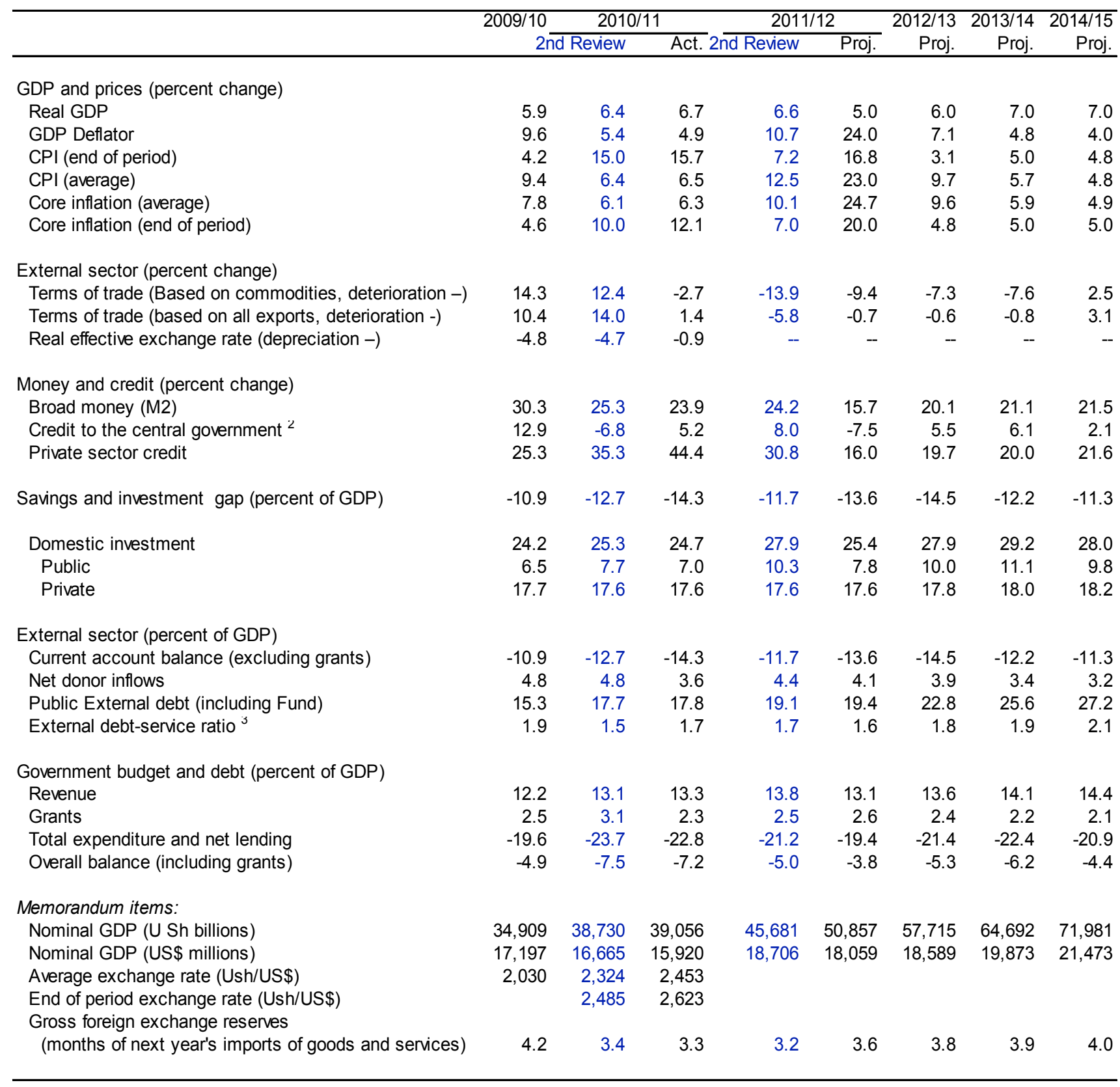

Sources: Ugandan authorities; and IMF staff estimates and projections.

1 Fiscal year begins in July.

2 Percent of M3 at start of the period. Oil capital gains is included in FY10/11.

3 Percent of exports of goods and nonfactor services. 
Table 2a. Uganda: Fiscal Operations of the Central Government, FY2009/10-2014/15

\begin{tabular}{|c|c|c|c|c|c|c|c|c|}
\hline & \multirow{2}{*}{$\begin{array}{r}\text { 2009/10 } \\
\text { Actual }\end{array}$} & \multicolumn{2}{|c|}{ 2010/11 } & \multicolumn{2}{|c|}{$2011 / 12$} & \multirow{2}{*}{$\begin{array}{r}\text { 2012/13 } \\
\text { Proj. }\end{array}$} & \multirow{2}{*}{$\begin{array}{r}\text { 2013/14 } \\
\text { Proj. }\end{array}$} & \multirow{2}{*}{$\begin{array}{r}2014 / 15 \\
\text { Proj. }\end{array}$} \\
\hline & & Review & Actual & 2nd Review & Proj. & & & \\
\hline & \multicolumn{8}{|c|}{ (USh Billions) } \\
\hline Total revenue and grants & 5,136 & 6,275 & 6,100 & 7,420 & 7,964 & 9,288 & 10,528 & 11,892 \\
\hline Revenue & 4,273 & 5,066 & 5,210 & 6,285 & 6,666 & 7,878 & 9,102 & 10,391 \\
\hline Tax & 4,067 & 4,818 & 4,958 & 6,002 & 6,374 & 7,557 & 8,761 & 10,016 \\
\hline International trade taxes & 352 & 635 & 455 & 519 & 584 & 698 & 718 & 801 \\
\hline Income taxes & 1,361 & 2,381 & 1,750 & 2,220 & 2,227 & 2,533 & 2,960 & 3,360 \\
\hline Excises & 1,025 & 1,616 & 1,186 & 1,380 & 1,478 & 1,742 & 2,095 & 2,345 \\
\hline Value-added tax & 1,329 & 2,298 & 1,567 & 1,884 & 2,085 & 2,585 & 2,988 & 3,510 \\
\hline Nontax & 206 & 248 & 252 & 283 & 292 & 321 & 341 & 375 \\
\hline Grants & 863 & 1,209 & 891 & 1,136 & 1,298 & 1,410 & 1,426 & 1,501 \\
\hline Budget support & 467 & 505 & 515 & 488 & 665 & 691 & 620 & 605 \\
\hline Project grants & 396 & 704 & 375 & 647 & 633 & 719 & 806 & 897 \\
\hline Expenditures and net lending & 6,836 & 9,162 & 8,900 & 9,705 & 9,876 & 12,339 & 14,517 & 15,069 \\
\hline Current expenditures & 4,308 & 5,749 & 5,963 & 4,838 & 5,629 & 6,321 & 7,061 & 7,756 \\
\hline Wages and salaries & 1,308 & 1,639 & 1,664 & 1,758 & 2,034 & 2,309 & 2,588 & 2,879 \\
\hline Interest payments & 386 & 409 & 423 & 441 & 672 & 742 & 841 & 936 \\
\hline Other current & 2,614 & 3,700 & 3,875 & 2,639 & 2,923 & 3,271 & 3,633 & 3,941 \\
\hline o/w exceptional security & 437 & 990 & 990 & 268 & 323 & 0 & 0 & 0 \\
\hline o/w power sector subsidies & 193 & 92 & 189 & 92 & 413 & $\ldots$ & $\ldots$ & $\ldots$ \\
\hline Development expenditures & 2,312 & 3,033 & 2,774 & 4,743 & 3,994 & 5,827 & 7,236 & 7,066 \\
\hline External/donor-financed projects & 889 & 1,592 & 1,042 & 2,063 & 1,728 & 2,660 & 3,517 & 3,290 \\
\hline o/w Entebbe hwy, road equipment & & & & 244 & 282 & 1,087 & 368 & 315 \\
\hline Government of Uganda investment & 1,423 & 1,441 & 1,732 & 2,679 & 2,266 & 3,167 & 3,720 & 3,776 \\
\hline o/w Karuma & & 181 & 0 & 858 & 448 & 776 & 1,009 & 503 \\
\hline o/w Oil Refinery & & & $\ldots$ & 15 & 17 & 817 & 951 & 0 \\
\hline Net lending and investment & -37 & -57 & -30 & -40 & -40 & -40 & -40 & -40 \\
\hline Other spending & 253 & 437 & 194 & 164 & 293 & 231 & 259 & 288 \\
\hline $\mathrm{o} / \mathrm{w}$ power sector arrears & & & & & 208 & & & \\
\hline \multicolumn{9}{|l|}{ Overall balance } \\
\hline Including grants & $-1,699$ & $-2,887$ & $-2,800$ & $-2,284$ & $-1,912$ & $-3,052$ & $-3,988$ & $-3,178$ \\
\hline Excluding grants & $-2,562$ & $-4,096$ & $-3,691$ & $-3,420$ & $-3,210$ & $-4,462$ & $-5,414$ & $-4,679$ \\
\hline Financing & 1,532 & 2,888 & 3,031 & 2,284 & 1,911 & 3,060 & 3,998 & 3,187 \\
\hline External financing (net) & 784 & 951 & 723 & 1,355 & 1,306 & 2,055 & 2,779 & 2,422 \\
\hline Disbursement & 919 & 1,125 & 878 & 1,538 & 1,517 & 2,252 & 3,004 & 2,695 \\
\hline Budget support & 236 & 237 & 233 & 122 & 422 & 310 & 293 & 302 \\
\hline Concessional project loans & 683 & 888 & 645 & 1,172 & 813 & 1,166 & 1,246 & 1,347 \\
\hline Non-concessional borrowing & & & & 244 & 282 & 775 & 1,465 & 1,046 \\
\hline Amortization (-) & -135 & -156 & -146 & -171 & -197 & -245 & -273 & -322 \\
\hline Exceptional financing $2 /$ & -26 & -19 & -9 & -13 & -14 & -17 & -5 & -6 \\
\hline Domestic financing (net) & 749 & 1,937 & 2,307 & 929 & 605 & 1,005 & 1,218 & 766 \\
\hline Bank financing & 811 & 1,545 & 1,624 & 829 & 481 & 666 & 884 & 368 \\
\hline o/w Bank of Uganda & 473 & 1,796 & 1,285 & 829 & 281 & 466 & 684 & 168 \\
\hline $\mathrm{o} / \mathrm{w}$ Petroleum fund withdrawals & & 0 & 0 & 316 & 52 & 776 & 1,009 & 503 \\
\hline o/w Energy Fund drawdowns & & 0 & 147 & 513 & 396 & 0 & 0 & \\
\hline o/w Bank of Uganda Repayments & & 0 & 0 & 0 & 0 & -310 & -326 & -335 \\
\hline o/w commercial banks & 338 & -252 & 339 & 0 & 200 & 200 & 200 & 200 \\
\hline Nonbank financing & -62 & 392 & 683 & 100 & 124 & 340 & 335 & 398 \\
\hline E\&O/fin. gap (- is gap, + is surplus) & -167 & 0 & 231 & 0 & 0 & 8 & 9 & 10 \\
\hline \multicolumn{9}{|l|}{$\begin{array}{l}\text { Memorandum Items: } \\
\text { Petroleum revenues (Ush billions) }\end{array}$} \\
\hline Inflows (including interest) & & & 1,192 & 27 & 1,312 & 123 & 90 & 44 \\
\hline Withdrawals & & & -- & 316 & 52 & 776 & 1,009 & 503 \\
\hline Stock at end period & & & 1,192 & 904 & 2,452 & 1,799 & 880 & 421 \\
\hline Rev, including petroleum revenue inflows & & & 6,402 & 6,352 & 7,978 & 8,000 & 9,192 & 10,435 \\
\hline Overall bal, incl. grants and petr. rev. inflows & & & $-1,608$ & $-2,217$ & -599 & $-2,929$ & $-3,898$ & $-3,134$ \\
\hline
\end{tabular}

Sources: Ugandan authorities; and IMF staff estimates and projections. 
Table 2b. Uganda: Fiscal Operations of the Central Government, FY2009/10-2014/15

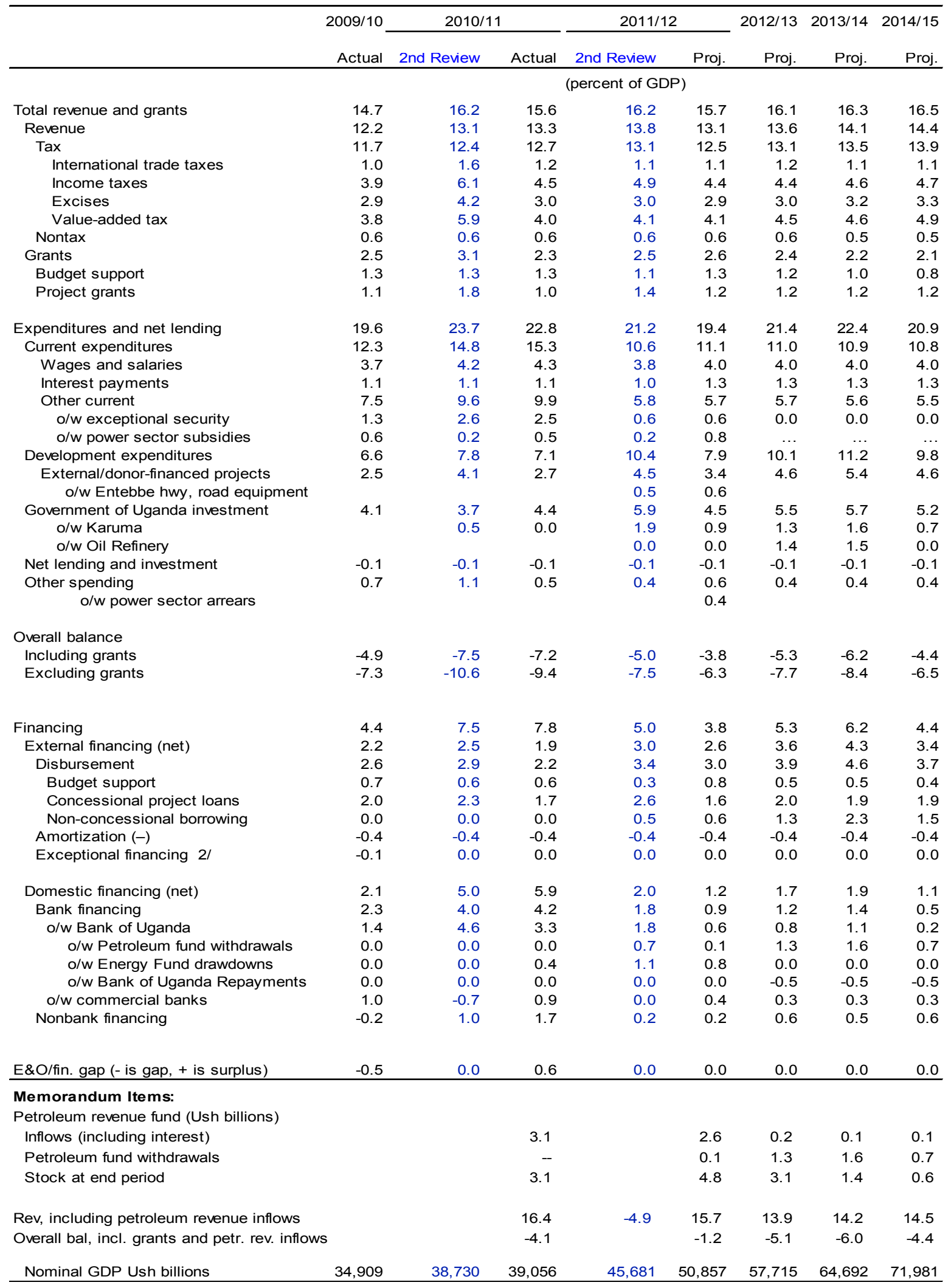

Sources: Ugandan authorities; and IMF staff estimates and projections. 
Table 2c: Uganda: Quarterly Fiscal Operations of the Central Government, 2011/2012

\begin{tabular}{|c|c|c|c|c|c|}
\hline & \multicolumn{5}{|c|}{$2011 / 2012$} \\
\hline & $\begin{array}{l}\text { Q1 } \\
\text { Prov. }\end{array}$ & $\begin{array}{r}\text { Q2 } \\
\text { Proj. }\end{array}$ & $\begin{array}{r}\text { Q3 } \\
\text { Proj. }\end{array}$ & $\begin{array}{r}\text { Q4 } \\
\text { Proj. }\end{array}$ & $\begin{array}{r}\text { Annual } \\
\text { Proj. }\end{array}$ \\
\hline & \multicolumn{5}{|c|}{ (Ush billions) } \\
\hline Total Revenue and Grants & 1,535 & 2,088 & 2,149 & 2,192 & 7,964 \\
\hline Revenue & 1,370 & 1,683 & 1,753 & 1,860 & 6,666 \\
\hline Grants & 165 & 405 & 396 & 332 & 1,298 \\
\hline Budget support & 107 & 195 & 214 & 149 & 665 \\
\hline Project grants & 58 & 210 & 182 & 183 & 633 \\
\hline Expenditure and Lending & 2,118 & 2,684 & 2,694 & 2,380 & 9,876 \\
\hline Current Expenditures (incl thermal) & 1,246 & 1,527 & 1,505 & 1,350 & 5,629 \\
\hline Wages \& Salaries & 441 & 490 & 526 & 577 & 2,034 \\
\hline Interest Payments & 163 & 153 & 154 & 201 & 672 \\
\hline Other & 642 & 884 & 825 & 572 & 2,923 \\
\hline o/w exceptional security & 145 & 88 & 89 & 0 & 323 \\
\hline o/w power sector subsidies & 0 & 142 & 141 & 130 & 413 \\
\hline Development Expenditures (excl thermal) & 626 & 1,011 & 1,188 & 1,169 & 3,994 \\
\hline External/donor-financed projects & 171 & 628 & 473 & 456 & 1,728 \\
\hline o/w Entebbe hwy, road equipment & 0 & 0 & 169 & 113 & 282 \\
\hline Government of Uganda investment & 455 & 383 & 715 & 713 & 2,266 \\
\hline o/w Karuma & 0 & 0 & 448 & 0 & 448 \\
\hline o/w Oil Refinery & 0 & 4 & 4 & 8 & 17 \\
\hline Net Lending \& Other spending & 242 & 146 & 0 & -135 & 253 \\
\hline o/w power sector arrears & 192 & 16 & 0 & 0 & 208 \\
\hline \multicolumn{6}{|l|}{ Overall balance } \\
\hline Including grants & -583 & -595 & -545 & -188 & $-1,912$ \\
\hline Excluding grants & -748 & $-1,001$ & -941 & -521 & $-3,210$ \\
\hline Financing & 583 & 595 & 545 & 188 & 1,911 \\
\hline External Financing net & 107 & 441 & 512 & 246 & 1,306 \\
\hline Disbursement & 167 & 504 & 573 & 274 & 1,517 \\
\hline Budget support & 0 & 140 & 282 & 0 & 422 \\
\hline Project loans & 167 & 363 & 151 & 132 & 813 \\
\hline Non-concessional borrowing & 0 & 0 & 140 & 142 & 282 \\
\hline Amortisation (-) & -54 & -62 & -54 & -27 & -197 \\
\hline Exceptional financing & -6 & -1 & -6 & -1 & -14 \\
\hline Domestic financing (net) & 476 & 154 & 33 & -58 & 605 \\
\hline Bank financing & -108 & 226 & 183 & 179 & 481 \\
\hline o/w Bank of Uganda & 0 & 0 & 33 & 248 & 281 \\
\hline o/w Petroleum fund withdrawals & & & 52 & 0 & 52 \\
\hline o/w Energy Fund drawdowns & 0 & 0 & 396 & 0 & 396 \\
\hline o/w Bank of Uganda Repayments & & & & & 0 \\
\hline o/w commercial banks & -108 & 226 & 150 & -68 & 200 \\
\hline Nonbank Financing & 583 & -72 & -150 & -237 & 124 \\
\hline Errors and omissions/financing gap & 0 & 0 & 0 & 0 & 0 \\
\hline
\end{tabular}

Sources: Ugandan authorities; and IMF staff estimates and projections. 
Table 3. Uganda: Monetary Accounts, FY2009/10-2014/15 ${ }^{1}$

(USh billions; end of period, unless otherwise indicated)

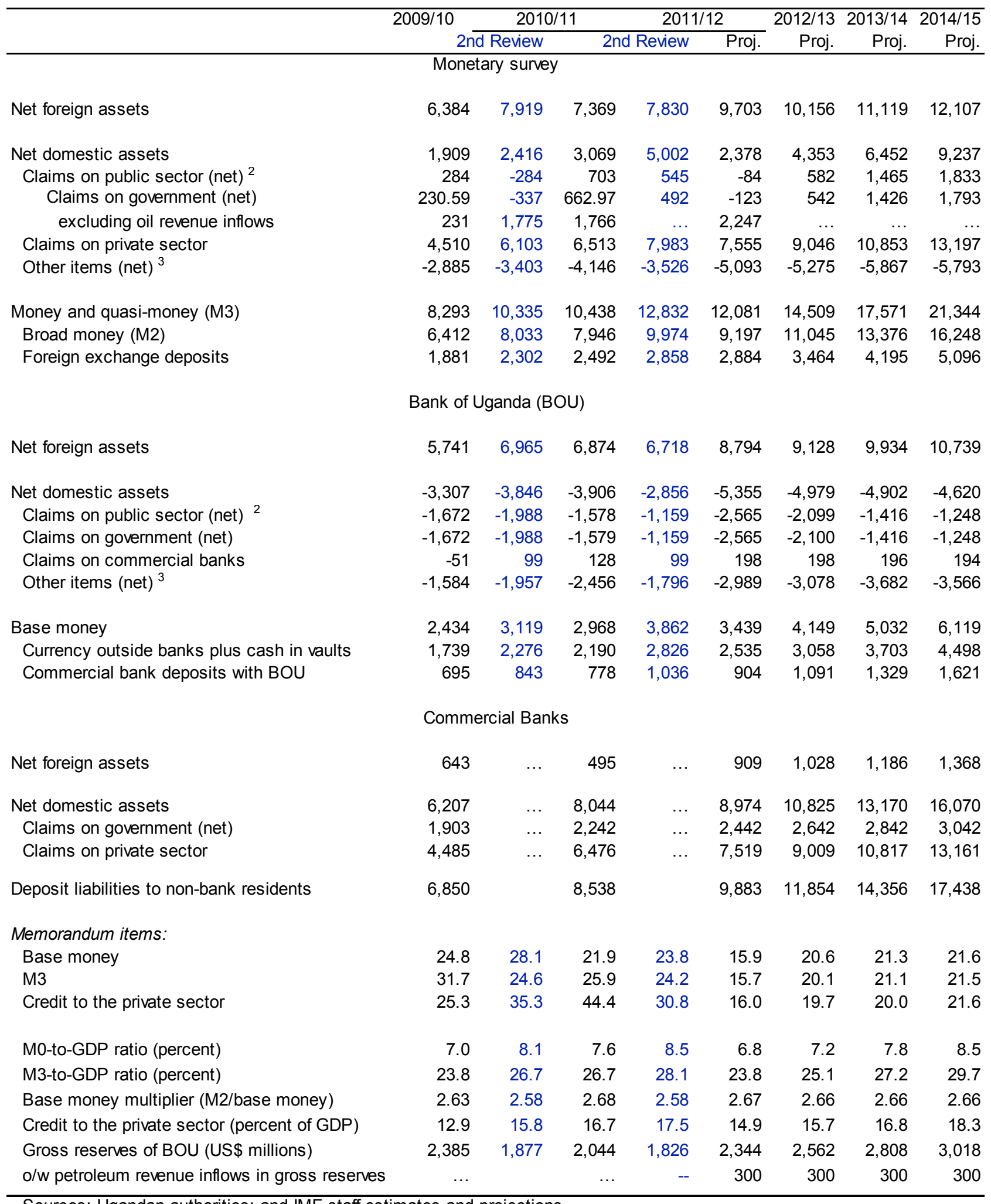

Sources: Ugandan authorities; and IMF staff estimates and projections.

${ }^{1}$ Fiscal year begins in July.

2 The public sector includes the central government, the public enterprises, and the local government.

${ }^{3}$ Including valuation effects and the BOU's claims on the private sector. 
Table 4. Uganda: Balance of Payments, FY2009/10-2014/15

\begin{tabular}{|c|c|c|c|c|c|c|}
\hline & $2009 / 10$ & $2010 / 11$ & $\begin{array}{r}2011 / 12 \\
\text { Proj. }\end{array}$ & $\begin{array}{r}2012 / 13 \\
\text { Proj. }\end{array}$ & $\begin{array}{r}2013 / 14 \\
\text { Proj. }\end{array}$ & $\begin{array}{r}2014 / 15 \\
\text { Proj. }\end{array}$ \\
\hline & \multicolumn{6}{|c|}{ (US\$ millions) } \\
\hline Current account & $-1,646$ & $-2,062$ & $-2,212$ & $-2,472$ & $-2,238$ & $-2,245$ \\
\hline Trade balance & $-1,698$ & $-2,309$ & $-2,431$ & $-2,281$ & $-2,209$ & $-2,283$ \\
\hline Exports, f.o.b. & 2,317 & 2,311 & 2,631 & 3,088 & 3,396 & 3,777 \\
\hline Of which: coffee & 262 & 371 & 423 & 444 & 467 & 491 \\
\hline Imports, f.o.b. & $-4,015$ & $-4,620$ & $-5,061$ & $-5,368$ & $-5,605$ & $-6,060$ \\
\hline Of which: oil & -486 & -659 & -746 & -801 & -870 & -946 \\
\hline Of which: government, infrastructure related & -171 & -167 & -481 & -589 & -817 & -820 \\
\hline Services (net) & -533 & -791 & -878 & -877 & -795 & -798 \\
\hline Income (net) & -332 & -373 & -310 & -326 & -369 & -354 \\
\hline Of which: interest on public debt & -29 & -36 & -50 & -62 & -71 & -81 \\
\hline Transfers & 917 & 1,411 & 1,406 & 1,011 & 1,135 & 1,190 \\
\hline Private transfers & 687 & 741 & 720 & 788 & 945 & 1,009 \\
\hline Of which: workers' remittances (inflows) & 777 & 828 & 841 & 899 & 1,063 & 1,141 \\
\hline Official transfers & 230 & 671 & 686 & 223 & 190 & 180 \\
\hline Of which: budget support (including HIPC) & 230 & 221 & 236 & 223 & 190 & 180 \\
\hline capital gains tax & & 450 & 450 & 0 & 0 & 0 \\
\hline Capital and financial account & 1,811 & 1,258 & 2,523 & 2,704 & 2,502 & 2,468 \\
\hline Capital account & 195 & 160 & 225 & 232 & 248 & 267 \\
\hline Of which: project grants & 195 & 160 & 225 & 232 & 248 & 267 \\
\hline Financial account & 1,615 & 1,098 & 2,298 & 2,472 & 2,255 & 2,201 \\
\hline Foreign direct and portfolio investment & 871 & 907 & 1,050 & 1,186 & 1,383 & 1,562 \\
\hline Other investment & 744 & 190 & 1,248 & 1,286 & 872 & 639 \\
\hline Of which: & & & & & & \\
\hline Public sector (net) & 386 & -136 & 769 & 1,046 & 939 & 808 \\
\hline SDR allocation & 224 & 0 & 0 & 0 & 0 & 0 \\
\hline Build-up/drawdown of petroleum fund & 0 & -450 & 150 & 200 & 50 & 50 \\
\hline Loan disbursements & 453 & 381 & 689 & 925 & 973 & 854 \\
\hline Project support (loans) & 337 & 279 & 289 & 376 & 383 & 402 \\
\hline Budget support (loans) & 116 & 102 & 150 & 100 & 90 & 90 \\
\hline Non-concessional borrowing & 0 & 0 & 100 & 250 & 450 & 312 \\
\hline Amortization due & -67 & -67 & -70 & -79 & -84 & -96 \\
\hline Commercial banks (net) & -5 & -93 & 114 & 19 & 37 & 45 \\
\hline Other private (net) & 363 & 419 & 666 & 621 & -4 & -114 \\
\hline Errors and omissions & 47 & 223 & 0 & 0 & 0 & 0 \\
\hline Overall balance & 212 & -581 & 311 & 231 & 264 & 223 \\
\hline Financing & -212 & 581 & -311 & -231 & -264 & -223 \\
\hline Central bank net reserves (increase $=-$ ) & -199 & 585 & -300 & -218 & -246 & -210 \\
\hline Of which: SDR allocation & -224 & 0 & 0 & 0 & 0 & 0 \\
\hline Use of Fund credit & -1 & -2 & -2 & -2 & -2 & -1 \\
\hline Memorandum items: & & & & & & \\
\hline Gross offical reserves $(\mathrm{BoU}) 1 /$ & 2,385 & 2,044 & 2,344 & 2,562 & 2,808 & 3,018 \\
\hline Months of imports of goods and services & 4.2 & 3.3 & 3.6 & 3.8 & 3.9 & 4.0 \\
\hline $\begin{array}{l}\text { Months of imports of } \mathrm{G} \& \mathrm{~S} \text { (excluding government } \\
\text { infrastructure related imports) }\end{array}$ & 4.3 & 3.4 & 3.8 & 4.1 & 4.3 & 4.4 \\
\hline Net donor support & 770 & 206 & 769 & 776 & 737 & 749 \\
\hline Of which: budget support (loans and grants) & 346 & 323 & 386 & 323 & 281 & 270 \\
\hline project support (loans and grants) & 532 & 439 & 514 & 607 & 630 & 669 \\
\hline Current account balance (percent of GDP) & -9.6 & -12.9 & -12.2 & -13.3 & -11.3 & -10.5 \\
\hline Current account balance (excluding grants) & -10.9 & -14.3 & -13.6 & -14.5 & -12.2 & -11.3 \\
\hline Trade balance (percent of GDP) & -9.9 & -14.5 & -13.5 & -12.3 & -11.1 & -10.6 \\
\hline Exports (percent of GDP) & 13.5 & 14.5 & 14.6 & 16.6 & 17.1 & 17.6 \\
\hline Imports (percent of GDP) & 23.3 & 29.0 & 28.0 & 28.9 & 28.2 & 28.2 \\
\hline
\end{tabular}

Sources: Ugandan authorities; and IMF staff estimates and projections.

${ }^{1}$ In FY 2010/11 there is revaluation gain of 241 million USD. 
Table 5. Uganda: Quantitative Assessment Criteria and Indicative Targets for June 30, $2011^{1}$

(Cumulative change from the beginning of the fiscal year, unless otherwise stated)

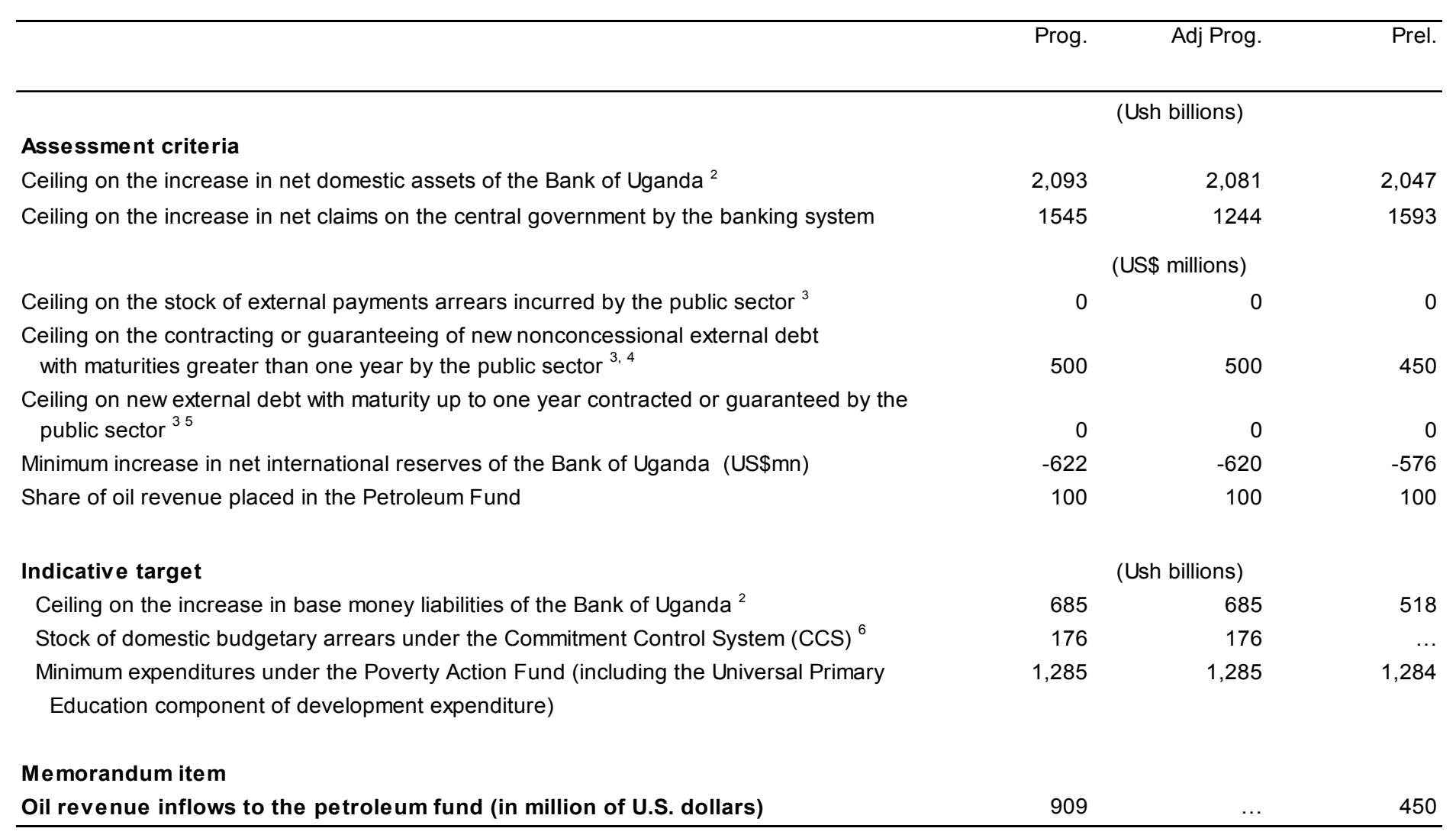

${ }^{1}$ Defined in the technical memorandum of understanding (TMU), all targets exclude oil revenues.

${ }^{2}$ Based on daily average.

${ }^{3}$ Continuous assessment criterion.

${ }^{4}$ To be used exclusively for infrastructure investment projects. Cumulative change from May, 2010.

${ }^{5}$ Excluding import-related credits.

${ }^{6}$ Monitored annually. 
Table 6. Banking Sector Indicators

\begin{tabular}{|c|c|c|c|c|c|c|c|}
\hline & De c-08 & Jun-10 & Sep-10 & Dec-10 & Mar-11 & Jun-11 & Sep-11 \\
\hline Regulatory capital to risk-weighted assets & 20.7 & 21.7 & 21.2 & 20.2 & 21.2 & 19.3 & 18.3 \\
\hline Regulatory tier 1 capital to risk-weighted assets & 18.7 & 19.2 & 18.8 & 17.5 & 18.9 & 17.3 & 16.2 \\
\hline NPLs to total gross loans & 2.2 & 3.3 & 2.8 & 2.1 & 2.5 & 1.6 & 1.8 \\
\hline NPLs to total deposits & 1.6 & 2.1 & 1.8 & 1.4 & 1.7 & 1.1 & 1.4 \\
\hline Earning assets to total assets & 75.6 & 74.9 & 76.7 & 77.1 & 73.6 & 74.8 & 74.3 \\
\hline Large exposures to gross loans & 31.0 & 35.4 & 35.5 & 35.7 & 38.6 & 41.7 & 38.3 \\
\hline Large exposures to total capital & 106.9 & 112.8 & 116.1 & 124.4 & 129.8 & 156.2 & 145.4 \\
\hline Return on assets & 4.0 & 3.0 & 2.4 & 3.0 & 3.3 & 3.1 & 3.6 \\
\hline Return on equity & 27.7 & 20.2 & 16.9 & 21.3 & 22.9 & 22.4 & 25.4 \\
\hline Net interest margin & 11.3 & 9.8 & 10.0 & 10.3 & 10.5 & 10.5 & 11.0 \\
\hline Liquid assets to total deposits & 48.1 & 41.6 & 40.5 & 39.8 & 40.5 & 35.6 & 36.2 \\
\hline Interbank borrowings to total deposits & 9.3 & 1.8 & 1.9 & 1.7 & 2.6 & 2.9 & 2.1 \\
\hline Forex exposure to regulatory tier 1 capital & -1.4 & -3.5 & -11.8 & -1.6 & -2.1 & -0.9 & -3.4 \\
\hline Forex loans to forex deposits & 65.5 & 52.1 & 54.4 & 65.2 & 63.4 & 68.6 & 66.8 \\
\hline Forex assets to forex liabilities & 102.7 & 98.4 & 96.3 & 98.0 & 98.1 & 100.1 & 98.1 \\
\hline
\end{tabular}

Source: Bank of Uganda 


\begin{tabular}{|c|c|c|c|}
\hline \multicolumn{4}{|c|}{$\begin{array}{l}\text { Table 7. Uganda: Structural Benchmarks Under the PSI }\left(2^{\text {nd }} \text { Review }\right) \\
\text { Status of Implementation }\end{array}$} \\
\hline Policy Measure & Macroeconomic Rationale & Date & Status \\
\hline $\begin{array}{l}\text { Government to begin to gazette and } \\
\text { publish on the internet the names of } \\
\text { beneficiaries (whether individual or } \\
\text { corporation) of all tax expenditures } \\
\text { (MEFP } \llbracket 5,24) \text {. }\end{array}$ & $\begin{array}{l}\text { Enforce discipline in } \\
\text { issuance of tax exemptions. }\end{array}$ & $\begin{array}{l}\text { September } \\
30,2011 \text {, and } \\
\text { quarterly } \\
\text { thereafter }\end{array}$ & $\begin{array}{l}\text { Met with delay - } \\
\text { accomplished on } \\
\text { December 9, } 2011 .\end{array}$ \\
\hline $\begin{array}{l}\text { URA to issue and begin to enforce } \\
\text { proposed transfer pricing guidelines } \\
\text { (MEFP } \llbracket 5,24 \text { ). }\end{array}$ & $\begin{array}{l}\text { To reduce tax planning and } \\
\text { prepare for large scale } \\
\text { petroleum revenues. }\end{array}$ & $\begin{array}{l}\text { Issued by } \\
\text { June } 30 \text {, } \\
2011 \text {, for } \\
\text { enforcement } \\
\text { beginning in } \\
\text { July } 2011 .\end{array}$ & Met. \\
\hline $\begin{array}{l}\text { Government to maintain transparency } \\
\text { over the treatment of unspent } \\
\text { budgetary funds at the end of the } \\
\text { fiscal year by (i) publishing the } \\
\text { balances as at June } 30 \text { and } \\
\text { September } 30 \text { on all government } \\
\text { accounts in the BoU and commercial } \\
\text { banks, and (ii) in order to spend any } \\
\text { balances held over from the previous } \\
\text { year beyond end-June, parliamentary } \\
\text { approval as well as supporting work } \\
\text { and procurement plans will be } \\
\text { required } \\
\text { (MEFP } \llbracket 32 \text { ). }\end{array}$ & $\begin{array}{l}\text { To enhance budgetary } \\
\text { discipline and promote } \\
\text { fiscal transparency. }\end{array}$ & $\begin{array}{l}\text { July } 31, \\
2011, \text { and } \\
\text { October } 30 \\
2011, \\
\text { respectively. }\end{array}$ & $\begin{array}{l}\text { Partly met with delay. } \\
\text { Central government } \\
\text { accounts went to zero } \\
\text { on June } 30 \text {, but local } \\
\text { government accounts } \\
\text { remained. Balances } \\
\text { on these were } \\
\text { published on Dec 12, } \\
\text { 2011. Parliament did } \\
\text { not re-appropriate the } \\
\text { balances however. }\end{array}$ \\
\hline $\begin{array}{l}\text { Begin submitting to Cabinet regular } \\
\text { quarterly reports on unpaid bills of } \\
\text { nine central government ministries } \\
\text { based on data in the Commitment } \\
\text { Control System (CCS) for the } \\
\text { previous quarter of the fiscal year } \\
\text { (MEFP } \$ 5,34 \text { ). }\end{array}$ & $\begin{array}{l}\text { To facilitate control and } \\
\text { elimination of expenditure } \\
\text { arrears }\end{array}$ & $\begin{array}{l}\text { June 30, } \\
2011, \text { for the } \\
\text { report } \\
\text { covering Q3 } \\
\text { of } \\
\text { FY2010/11, } \\
\text { and quarterly } \\
\text { thereafter. }\end{array}$ & $\begin{array}{l}\text { Partly met with delay. } \\
\text { A report for Q1 } \\
\text { FY2011/12 for } 7 \text { of the } \\
9 \text { ministries was } \\
\text { submitted to Cabinet } \\
\text { on December } 19 \text {, } \\
2011 .\end{array}$ \\
\hline $\begin{array}{l}\text { Extend the "straight-through payment" } \\
\text { system (STP) now employed for } \\
\text { pensions to the utility (electricity, } \\
\text { water) sector (MEFP } \llbracket 5,33 \text { ). }\end{array}$ & $\begin{array}{l}\text { Help control accumulation } \\
\text { of arrears }\end{array}$ & July 1, 2011. & $\begin{array}{l}\text { Not met }- \text { to be } \\
\text { replaced by new } \\
\text { benchmark. }\end{array}$ \\
\hline $\begin{array}{l}\text { As part of introduction of national } \\
\text { identification system, } 4 \text { million } \\
\text { additional citizens will have received } \\
\text { IDs (MEFP } \$ 5,30 \text { ). }\end{array}$ & $\begin{array}{l}\text { To support efforts to } \\
\text { strengthen revenue } \\
\text { collection and combat } \\
\text { money laundering and the } \\
\text { financing of terrorism. }\end{array}$ & $\begin{array}{l}\text { June } 30 \\
2012 \text {. }\end{array}$ & On track \\
\hline $\begin{array}{l}\text { Produce and disseminate within } \\
\text { government a monthly index of } \\
\text { economic activity relying on the } \\
\text { various high-frequency indicators } \\
\text { available (MEFP } \$ 5,29) \text {. }\end{array}$ & $\begin{array}{l}\text { To facilitate the conduct of } \\
\text { monetary policy. }\end{array}$ & $\begin{array}{l}\text { September } \\
30,2011, \text { and } \\
\text { quarterly } \\
\text { thereafter. }\end{array}$ & $\begin{array}{l}\text { Met with delay -first } \\
\text { monthly report } \\
\text { (through September } \\
\text { 2011) distributed on } \\
\text { December 9, 2011. }\end{array}$ \\
\hline $\begin{array}{l}\text { BoU to include in Quarterly Report } \\
\text { data on the net and gross positions of } \\
\text { government in the BoU (MEFP श5). }\end{array}$ & $\begin{array}{l}\text { Enhance central bank } \\
\text { independence and prepare } \\
\text { Bank of Uganda to move } \\
\text { toward inflation targeting. }\end{array}$ & $\begin{array}{l}\text { September } \\
30,2011, \text { and } \\
\text { quarterly } \\
\text { thereafter. }\end{array}$ & Met. \\
\hline
\end{tabular}




\section{APPENDIX I. LETTER OF INTENT}

Kampala, Uganda

December 20, 2011

Ms. Christine Lagarde

Managing Director

International Monetary Fund

Washington, DC 20431

Dear Ms. Lagarde:

On behalf of the Government of Uganda, I would like to provide you with an update on the progress we have made under our program backed by the IMF's Policy Support Instrument (PSI).

Since the last review, Uganda has faced the twin challenges of inflation and a volatile and fast depreciating exchange rate, which Government has fought successfully. This was done through aggressively constraining credit demand through the central bank rate, and resisted all temptations to support the Uganda Shilling, or ban food exports. Despite these challenges and turbulence, we have remained steadfast in implementing good macroeconomic policies that are now starting to pay off. Signs of price instability are beginning to abate and the exchange rate has been more stable, with the Uganda Shilling firming recently.

The spike in inflation emanated, in the first instance, from higher international and regional food prices, as well as a result of the depreciation of the Uganda shilling against major foreign currencies during the first three quarters of the year. The global economic outlook has adversely affected Uganda. Weaker global demand for Uganda's exports has contributed to a worsening in the current account of the balance of payments, and also tempered nonresident investment in our markets. The Government's refusal to ban food exports in order to keep domestic prices low embodies our deep commitment to maintaining a liberal trade regime.

The authorities met six out of the seven quantitative assessment criteria as at end-June 2011. The only criterion not met was Net Credit to Government (NCG) from the banking system, which was missed by about 0.9 percent of GDP as a result of inadvertent under-budgeting for important expenditure items, including civil service wages, road construction, and interest charges on public debt. The latter have risen as the Monetary Authority has tightened the stance of monetary policy. In addition, we incurred some expenditure arrears in the power sector, amounting to about 0.5 percent of GDP, as we continue to support the power sector in the face of increasing costs resulting from higher crude oil prices and a depreciating 
exchange rate. Following the clearing of arrears to the power sector incurred in the last fiscal year, Government is taking decisive steps to ensure that adequate provisions are made and any accumulation of arrears does not recur this year. End-user electricity tariffs will accordingly be increased early in the new year. I hereby request a waiver for the nonobservance of Net Credit to Government (NCG) quantitative assessment criteria for this.

Looking ahead, we request the modification of quantitative assessment criteria for endDecember 2011 and establishment of quantitative assessment criteria for end-June 2012, as set out in the attached Memorandum of Economic and Financial Policies (MEFP) and the Technical Memorandum of Understanding (TMU) that is a part of the MEFP. The MEFP also sets out the Government's objectives and policies for remainder of this financial year and sets out Government's medium term strategic goals. These goals are drawn from our National Development Plan (NDP), and emphasize the importance of scaling up infrastructure development to clear the most critical bottlenecks to growth and poverty reduction. The Government is taking measures to tighten fiscal and monetary policies to contain inflationary pressures while protecting medium-term growth. We will also place central efforts at enhancing revenues and strengthening public financial management in order to create a medium term macroeconomic policy framework that enables scaling up of infrastructure spending while rebuilding gross international reserves in line with the PSI objectives.

The Government believes the policies set forth in the MEFP are fully sufficient to achieve the objectives of our PSI-supported program. We stand ready to take any further measures that may become appropriate for this purpose and intend to work with the IMF and other development partners in the implementation of our program. We commit to consult with Fund staff in advance should revisions to the policies contained in the PSI be contemplated by the Government.

Sincerely yours, $/ \mathrm{s} /$

Ms. Maria Kiwanuka

Minister

Ministry of Finance, Planning and Economic Development

Attachments

Memorandum of Economic and Financial Policies

Technical Memorandum of Understanding

cc: Governor Emmanuel Tumusiime-Mutebile, Bank of Uganda 


\section{Attachment I. Memorandum of Economic and Financial Policies}

December 20, 2011

\section{INTRODUCTION}

1. The Government of Uganda remains committed to macroeconomic stability, sustainable economic growth and poverty reduction as set out in the National Development Plan. ${ }^{1}$ This Memorandum of Economic and Financial Policies (MEFP) summarizes the Government's strategy to achieve these goals. The Government of Uganda and the International Monetary Fund (IMF) are cooperating on the economic program through a three-year Policy Support Instrument (PSI). This MEFP describes performance under the PSI program through September 2011, specific policies and targets for 2011/12 and medium term objectives.

2. The Uganda Government is taking the necessary measures to deal with the external shocks to the economy and to reduce inflation to single-digit territory. Economic growth remains strong despite the exogenous shocks which have hit the economy. The authorities are revising the macroeconomic framework to curb the second round impact of these shocks on inflation and to ensure that competitiveness is not undermined. Both fiscal and monetary policies will remain tight in the short to medium term in order to reduce inflation to single digits by the end of 2012 .

\section{Purpose of the MEFP}

3. This memorandum updates Uganda's economic program under the three-year Policy Support Instrument (PSI) for the period 2010-13, approved by the IMF Executive Board on May 12, 2010. The second review of the PSI was completed in June 2011. Since then, global economic developments coupled with continued regional demand shocks and structural supply constraints for food have posed risks and challenges to the Ugandan economy, resulting in high inflation and exchange rate volatility. In the face of these risks, the Government has taken steps to contain inflationary pressures and exchange rate volatility. Government's key near-term objective is to reverse the acceleration in inflation over the coming year.

\footnotetext{
${ }^{1}$ http://www.finance.go.ug/index.php/publications/doc_download/80-national-development-plan.html
} 


\section{Performance under the PSI}

4. All the quantitative assessment criteria, except the one related to the ceiling on Net Credit to Government (NCG) by the banking system, were met. The NCG target was missed by about Ush 350 billion because of road construction bills which were not anticipated during the period, higher interest costs due to the increased interest rates, and a higher wage bill, also due to underestimation of the budget. To avoid these overruns in future, the Authorities have agreed, beginning in mid-December 2011, to submit to Cabinet regular quarterly reports on unpaid bills of spending units based on data in the Commitment Control System (CCS) for the previous quarter of the fiscal year. This will enable corrective actions to be taken within the budget to avoid the accumulation of arrears by the end of the fiscal year

5. Government acknowledges that implementation of agreed structural reforms through end-September was mixed. Only two of the seven structural benchmarks due were met: the URA issued and began to enforce transfer pricing guidelines, and publication of the net and gross positions of government in the BoU was achieved. Roll-out of the National Identification System is on track, as 4 million Ugandans are meant to have ID cards by June 30,2012 . Full roll-out of the national ID cards to all Ugandans is planned to take place by July 1, 2013. Most other measures have been or will be implemented with delay, mainly for technical reasons:

- $\quad$ Government has begun to gazette and publish on the Ministry of Finance, Planning and Economic Development (MoFPED) website the names of beneficiaries of all tax exemptions, as of December 9, 2011. ${ }^{2}$

- Government has posted on the MoFPED website the balances of unspent budgetary funds on all government accounts at the end of the fiscal year 2010/11 as of December 12, 2011. Government balances for central government agencies were zeroed out at end-June 2011, but there were some balances left on accounts of local governments. These unspent balances were however not re-appropriated by Parliament for FY 2011/12. ${ }^{3}$

- $\quad$ The structural benchmark on submitting to Cabinet regular quarterly reports on unpaid bills of spending units based on data from the Commitment Control System (CCS) was not done on time, but was introduced as of December 19, 2011.

\footnotetext{
${ }^{2}$ See http://www.finance.go.ug/index.php/publications/doc_download/219-gross-tax-payment-for-mofped2010-2011.html and http://www.finance.go.ug/index.php/publications/doc_download/224-gross-taxexpenditure-july-sept-2011-2012.html.

${ }^{3}$ See http://www.finance.go.ug/images/Authorised\%20unspent\%20balances\%20FY\%202010-11.pdf.
} 
- Government did not introduce "straight-through payments" for electricity and water bills of government organizations as planned in July. It intends to achieve the same objective — of strengthening the accountability of accounting officers in spending units - by publishing quarterly releases and actual payments for utilities on a disaggregated (vote) basis, and imposing administrative sanctions on those Accounting Officers found to have failed to settle legal obligations for power and water. ${ }^{4}$ ) The implementation of this reform began to be implemented on December 13, 2011. Government expects to reinforce the effect of this measure by agreeing with utility companies on installation of prepaid meters for water and electricity in government institutions.

- $\quad$ The structural benchmark to develop a set of high frequency indicators was partly met, as the BoU is working in collaboration with the Uganda Bureau of Statistics (UBOS) to develop a Composite Index of Economic Activity. BoU began to distribute it within government on December 9, 2011.

\section{ECONOMic AND Policy DeVelopments}

\section{Outturn in 2010/11}

6. Economic growth in $2010 / 11$ was 6.7 percent but the pace of growth declined in the second half of the fiscal year. The main drivers of economic growth were manufacturing, trade, construction, and transport and communication. In contrast, agricultural growth was very low because of adverse weather conditions.

7. Inflation, which fell between July and October 2010, began to pick-up towards the end of the year, and then accelerated during 2011. Annual headline and core inflation stood at 30.5 percent and 30.8 percent, respectively, in October 2011. Food inflation rose from 33.4 percent in June 2011 to 45.8 percent by October, while the increase in non-food inflation was from 7.9 percent to 22.8 percent in the same period. The rise in inflation is attributable to a number of factors: poor domestic harvests for most food crops; higher international commodity prices, particularly for food and fuel; higher inflation in the countries from which Uganda imports; and exchange rate depreciation. But monetary factors have also played a role. Private sector credit grew by 44 percent in 2010/11 fiscal year, and has remained high through September.

8. The balance of payments weakened significantly in 2010/11, mainly because of the deteriorating current account deficit, which widened as import growth outstripped that of exports, tourism receipts and remittances. Imports grew strongly because of higher

\footnotetext{
${ }^{4}$ See http://www.finance.go.ug/index.php/publications/doc download/227-budget-analysis-for-electricity-andwater-items-for-financial-year-201011.html
} 
international commodity prices and the rebound in domestic demand. The capital and financial account surplus fell to US\$ 1,258 million in 2010/11 from US\$ 1811 million in $2009 / 10$. Because of the deterioration of the current account, the overall balance of payments recorded a deficit of US\$ 581.4 million, compared with a surplus of US\$210.9 million in $2009 / 10$. This resulted in a reduction in gross international reserves to the equivalent of 3.3 months of imports of goods and services by end-FY 2010/11, compared to 4.2 months at the end of the previous fiscal year.

9. The deteriorating balance of payments has caused the Ugandan shilling to weaken against the US dollar and other major international currencies. In addition, speculative activities in the domestic interbank foreign exchange market caused some volatility in the market that BoU could only partly curtail through interventions. As a result, the nominal effective exchange rate depreciated by 16.0 percent in 2010/11 compared to a depreciation of 7.4 percent in 2009/10.

\section{Monetary policy}

10. Although fiscal and monetary policy management was not the main cause of inflation, the authorities now see a risk that second round effects are taking hold, and have taken measures to reduce aggregate demand by increasing interest rates. The Central Bank Rate (CBR) was introduced in July 2011 at a rate of 13 percent and subsequently raised four times to 23 percent in November. (See paragraph 29 below.) As a result, commercial banks have increased their prime lending interest rates by several percentage points, with some now as high as 29 percent. Moreover, the yields on government securities rose from 13.1 percent in June 2011 to 23.3 percent in October. In the short term, fiscal policy will remain tight to support monetary policy management, and the Government will make the necessary adjustments to fiscal policy in FY 2011/12 to be supportive of the BoU's disinflation effort.

\section{Financial sector}

11. A recent Financial Sector Assessment Program (FSAP) review commended the progress the authorities have made in the financial sector since the last review in 2005 . In particular, significant advances have been made in implementing risk-based supervision, exercising strong supervisory practices and complying with the 2005 Basel Core Principles (BCP) assessment, resulting in a more than adequately regulated and supervised financial sector. In wake of the challenges to the macroeconomic environment, and particularly the impact on interest rates and the quality of assets of the banking system, the FSAP recommends that $\mathrm{BoU}$ address the gaps within the existing legislative and regulatory framework, and strengthen collaboration with other jurisdictions to reduce cross-border banking and other related risks.

12. In particular, during FY 2010/11, private sector credit as a ratio of GDP increased to 17 percent, compared to 13 percent a year earlier. The FSAP noted that bank profitability has improved as cost-to-income ratios were reduced, and non-performing loans, which are a 
measure of asset quality, remained low, despite the rapid expansion of credit growth. Specifically, non-performing loans as a share of total loans fell to around 2 percent, from 4 percent in 2009. Nevertheless, the authorities recognize that the tighter policy stance will slow down private sector activity and, as noted by the recent FSAP, could lead to deterioration in the quality of bank assets.

13. As regards structural issues, legislation to enable banks to undertake bancassurance and offer Islamic financial products, and to introduce a capital charge for market risk, is before Cabinet. Legislation to strengthen anti-money laundering is also before Parliament, and the Uganda Retirement Benefits Regulatory Authority Act 2011 which establishes a regulatory framework for the entire pension sector was enacted in June 2011, which is the initial step in leveraging private sector savings to finance domestic investments.

\section{Fiscal performance during FY 2010/11}

14. Revenue collections during 2010/11 fiscal year rose, relative to the previous year, mainly due to the effects of exchange rate depreciation and stronger demand for consumption imports. Tax revenue (excluding oil capital gains taxes) for FY 2010/11was 12.7 percent of GDP. Tax revenue from PAYE, corporation tax, customs duties and VAT on imports was above target. However, VAT on domestic consumption (except beer and soft drinks) and local excise duties on cigarettes, sugar, mobile phone talk time, as well as domestic fees and licenses were below their respective targets.

15. Total expenditure to GDP was 22.8 percent in FY 2010/11, about 3 percentage points higher than in FY 2009/10. The sharp increase in government spending was due to a number of factors, including: increased security-related exceptional spending; increased wages and salaries for lower-paid cadres of civil servants; unanticipated pension obligations; underbudgeted transport sector bills; higher-than-forecast thermal power costs due to rising fuel prices; and increased police, security and other election-related activities. Some of these expenditures were unforeseen, leading to arrears on thermal power subsidies of about 0.5 percent of GDP which had to be paid in early FY 2011/12, and also contributing to the missed target on net credit to government. On a cash basis (excluding arrears), the central government deficit including grants for last fiscal year was 7.2 percent of GDP.

\section{Outlook and Medium-Term Policies}

\section{Macroeconomic Objectives and Outlook}

16. Government's primary macroeconomic objectives over the next two years are to reduce inflation and achieve sustainable economic growth. The economy is expected to slow down from 6.7 percent growth in 2010/11 to 5.0 percent in 2011/12, because of weaker global growth and the tight macroeconomic stance needed to curb inflation in Uganda. Real GDP growth is expected to recover to 6.0 percent in 2012/13 and 7.0 percent in outer years on the back of stronger domestic investment in agriculture, power and roads, and restoration 
of macroeconomic stability. The balance of payments is expected to remain under pressure, given rising investment on infrastructure projects including the oil sector, while mitigated by more FDI flows and portfolio investors' response to higher interest rates. Regional exports are expected to increase over the medium term in response to the current Government focus on investments that promote regional trade, taking advantage of the high regional demand particularly for food and light manufactures.

\section{Monetary policy}

17. The BoU's primary objective is to bring down core inflation towards its 5 percent target in the medium term. In addition, the BoU aims to rebuild foreign exchange reserves equivalent to a minimum level of 4 months of imports by FY 2014/15. The BoU will continue to maintain a flexible exchange rate regime to ensure the necessary adjustments in the economy following external shocks, and will also continue to maintain an open capital account.

18. Overall (headline) inflation is projected to decline to about 17 percent by June 2012 . Core inflation is projected at 20 percent by June 2012 before declining to about 5 percent in June 2013. The outlook indicates that consumer prices will ease after peaking this year, as food prices gradually moderate and aggregate demand is reined in through tighter fiscal and monetary policies. The speed at which inflation falls will to some extent depend on how quickly the supply side shocks to food prices dissipate and the extent to which further adjustment in the exchange rate is necessary to equilibrate the balance of payments.

19. Looking ahead, the BoU will set the CBR to achieve its path for the reduction of inflation. If inflation is higher than forecast over the coming months, the BoU will raise the $\mathrm{CBR}$, to ensure that the real interest rate increases. The BoU is committed to act in a manner which will stabilize inflation, by raising the CBR by more than the change in the inflation forecast, i.e. by tightening further if the inflation outlook deteriorates.

\section{Fiscal strategy for 2011/12 and the medium term}

20. The Budget for FY 2011/12 is consistent with the understandings reached in the context of the PSI. The main thrust of the 2011/12 budget is to address the challenges of rising inflation, high unemployment, inadequate infrastructure development particularly in the power and roads sectors, improving social infrastructure and improving social service delivery. Addressing these constraints will require restructuring the budget to refocus it to the medium term priorities in order to create fiscal space through further expenditure efficiency measures.

21. Government recognizes the importance of revenue enhancement for ensuring fiscal sustainability. Nevertheless, non-oil tax revenue to GDP is projected to fall slightly to 12.5 percent of GDP in FY 2011/12, given the forecast slower real GDP growth. The 
expected revenue outturn will be helped by the reduction in tax exemptions, administration efficiency gains, and the exchange rate depreciation.

22. Total expenditure is projected to decline to 19.4 percent of GDP in FY 2011/12. The sharp depreciation of the Uganda shilling against the US dollar has increased the shilling expenditure requirements of dollar-denominated components of the FY 2011/12 Budget. To the extent possible, supplementary expenditure pressures will be accommodated within the resource envelope for 2011/12 fiscal year. In the event that higher nominal revenues arise from the impact of inflation on the tax base, relative to the approved FY 2011/2012 Budget, some of these extra revenues will be used to finance expenditure pressures that may arise during 2011/12 fiscal year, while the remainder will be set aside to tighten the fiscal stance as needed to support the Bank of Uganda's disinflation effort.

23. The fiscal deficit including foreign grants but excluding oil revenues was 7.2 percent of GDP in FY 2010/11, and is projected to decline to below 4 percent in FY 2011/12 as exceptional military expenditures come to an end, and consistent with the objective of reducing inflation. This deficit will be financed primarily through external borrowing, with donor disbursements projected to increase to 3 percent of GDP in FY 2011/12 compared to 2.2 percent of GDP a year before. Banking system financing is projected to decline significantly from 4.2 percent of GDP in 2010/11 to about 1 percent of GDP in 2011/12, with the main source of financing being drawdown from the Energy Fund to cover payments needed to initiate the Karuma hydropower project.

24. Government is committed to reducing the scope of tax exemptions and tax holidays in order to boost domestic revenue collections. Government has begun publishing the names and amounts of beneficiaries of tax expenditures on the MoFPED website on a quarterly basis (as of December 2011). Further, Government is reviewing tax holidays and exemptions with a view to streamlining them into the tax code. Tax exemptions on hotels have been terminated, and we have issued and begun to implement new transfer pricing guidelines. It is also streamlining agricultural processing exemptions and the 10-year tax holiday under the Income Tax Act, while also eliminating VAT exemptions on sales of motor vehicles or trailers of a carrying capacity of 3.5 tons or more designed for the transport of goods. As stated in the MEFP of June 15, 2011, some tax policy reforms will take time to prepare, and in a few cases additional technical assistance may be required. We therefore intend, in the context of the 2012/13 budget, to propose elimination of a number of additional exemptions, particularly of intermediate sales under the VAT. Beginning in 2012/13, URA hopes to begin paying VAT refunds directly, rather than through budgetary appropriation, in order to expedite refunds and improve the efficiency of this tax.

25. As noted at the time of the second PSI review, Government is working on amendments to the Public Finance and Accountability Act (PFAA) to enhance the predictability of the budget by considering the creation of a contingency fund to finance emergencies and supplementary budgets, with clear criteria for its use. The revised act- 
which is expected to be submitted to Parliament during FY 2011/12 —would also restrictvirements (reallocations) between and within spending ministries. Finally, as noted below, the revised PFAA will establish an appropriate mechanism for oil revenue management, including by establishing a Petroleum Fund (see paragraphs 36-37 below).

26. Government received almost US\$450 million in oil capital gains tax revenues in FY 2010/11. These funds have been set aside as part of a special account in the Bank of Uganda, and are earmarked for the Karuma Hydropower Project. The foreign exchange equivalent was, however, sold to the BoU in July to boost reserves in the period before a formal Petroleum Fund is established. Future oil revenues will be retained on the petroleum account of government in the BoU, and not comingled with BoU's international reserves.

27. Government expenditure policy in 2011/12 will emphasize a prudent expansion in public investment in line with the NDP priorities but also consistent with availability of resources, taking into consideration the current domestic economic developments. Government will undertake a review of the implementation of the NDP in early-2012 to assess implementation constraints including availability of resources and recent developments in the economy. In the medium term, as fiscal space and implementation capacity are expanded, the fiscal strategy will focus on wider implementation of key priority infrastructure projects in the NDP to unlock the most critical binding constraints to economic growth. In addition to the on-going infrastructure projects already in the MTEF, the new projects which will commence in FY2011/12 are the Karuma hydropower project and the Kampala-Entebbe express highway.

28. Other projects to be implemented in the medium term include the rehabilitation of Tororo-Pakwach railway, construction of Kampala-Jinja dual carriage way, and Kampala metropolitan roads to decongest the traffic in and around Kampala city. These projects are to be financed mainly by some nonconcessional borrowing for the highway, government's own current domestic revenues (including oil revenues) and, with time possibly the proceeds from the sale of infrastructure bonds. In particular, Government is considering issuance of an infrastructure bond in the third year of construction of the Karuma hydropower project, when the oil revenue savings at BoU are expected to be exhausted. It is also expected that limited infrastructure bonds may be issued to meet start up costs for other critical projects; however, these issuances will be fully consistent with the macroeconomic stance discussed and agreed with the IMF. Finally, at this stage, Government is not requesting an increase in the nonconcessional borrowing ceiling under the PSI, though it may do so at future reviews

\section{STRUCTURAL ISSUES AND REFORMS}

\section{Enhancing the framework for monetary policy}

29. To modernize monetary policy framework, the BoU introduced an Inflation Targeting Lite (ITL) monetary policy framework in July 2011. Under this framework, the operating target of monetary policy is a monetary policy interest rate called the Central Bank Rate 
(CBR), which targets the 7-day interbank interest rate. The daily operations of monetary policy are thus geared at influencing the supply of liquidity in the interbank money market so as to align the 7-day interbank money market rate within a band around the CBR. The ITL framework has improved the transparency of monetary policy. The BoU has expanded and strengthened its communication strategy to include periodic press briefings explaining the decisions of the Monetary Policy Committee. To enhance the effectiveness of monetary policy, the BoU—in collaboration with the Uganda Bureau of Statistics (UBOS) - has developed a Composite Index of Economic Activity as one of the needed high frequency indicators for monetary policy analysis. The BoU has begun to disseminate an early version of this data within government. In this regard, the BoU has requested that the International Monetary Fund provide technical assistance and advice on enhancing the compilation of the Index and other high frequency indicators needed for monetary policy analysis.

\section{Revenue administration modernization}

30. Government plans to continue with revenue administration reforms in addition to the tax policy changes noted above. To improve tax administration and reduce cost of compliance, the use of e-tax services is being rolled out across the country to facilitate taxpayers' registration, filing and payments. The implementation of the e-tax will continue in a phased manner, starting with large and medium taxpayers. Introduction of e-tax will allow URA to pay VAT refunds directly, rather than through budgetary appropriation, which Government hopes to begin doing in 2012/13. Introduction of the national identification system will proceed in stages, with an initial 4 million citizens covered by June 30, 2012. Full roll-out of the National ID project will take place by July 1, 2013.

\section{Public Finance Management}

31. During FY 2011/12, the Government will propose to Parliament revisions to the Public Finance and Accountability Act (PFAA) of 2003 with the aim of strengthening public finance management. It was submitted to Cabinet in late November 2011. Key objectives in this regard include introduction of a contingency fund to cater for any supplementary budgets or national emergencies, with clear guidelines to control spending pressures. The revised PFAA will also restrict virement (reallocation) abilities both across and within spending ministries. In the new PFAA, Government will ensure that any significant reallocation of spending authority will require ex-ante approval from parliament. Further, to ensure realism

and credibility of the budget, and strict adherence to annual work plans of spending units, the authorities plan to consider in the PFAA amendments advancing the budget timetable to enable Parliamentary budgetary approval before the start of each new fiscal year. Over the medium term, Government intends to move to a treasury single account system for administering government finances, recognizing this practice will improve cash management and reduce the cost of government borrowing. In this regard, Government requests IMF technical assistance on establishment of a treasury single account. 
32. In addition, the revised PFAA will also clarify and set limits on the ability of government to carry forward expenditure appropriation from one fiscal year to the next. In the meantime, to limit the potential for abuse and diversion of funds, government took strong measures to control unspent balances at the end of FY 2010/11: all central government agency accounts were zeroed out by June 30,2011, and the balances returned to the Uganda Consolidated Fund (UCF). However, local governments were allowed by the Secretary to the Treasury (albeit not by parliament) to retain some central government funds disbursed in FY 2010/11. These balances (both in the BoU and in commercial banks) as at June 30 were published on the MoFPED website to enhance transparency.

33. Government acknowledges that internal controls to prevent the accumulation of expenditure arrears need to be strengthened, despite the measures set out in our 2007 Debt Strategy. In the context of amendments to the PFAA, Government will take steps to strengthen the Commitment Control system (CCS), including by introducing strong sanctions - including immediate dismissal — on Accounting Officers who are found to have incurred expenditure obligations outside the CCS. In the meantime, to address persistent reports of arrears on electricity and water, MoFPED has begun to publish on a quarterly basis the releases and actual payments made for these utilities, by vote and including the name of the responsible Accounting Officer in charge at that time. Accounting Officers who are found to have run persistent arrears on power and water will face administrative sanction, and we commit to report on the actions taken at the time of the next PSI review.

34. Further, to control the growth of expenditure arrears, the Minister of Finance, Planning and Economic development has begun to submit to Cabinet reports on unpaid bills for nine central government ministries on a quarterly basis. These institutions are: Works and Transport, State House/Presidency, Ministry of Public Service, Prisons, Police, Ministry of Justice and Constitutional Affairs, Education, Health and Ministry of Finance, Planning and Economic Development. These reports will cover civil works certificates, utilities, wages and pensions, compensations and/or court awards, and power subsidies. The reports will also include the unspent balances from the previous quarter. More fundamentally, Government requests for IMF technical assistance to boost capacity in the area of control of expenditure arrears.

35. In the context of strengthened control over expenditure arrears, Government firmly intends to avoid accumulation of arrears in the power sector, and a supplementary budget will be submitted to Parliament by April 30, 2012 to cover any residual subsidy requirements that would be due. Subsidy requirements in the budget will be consistent with the power sector tariff structure actually set by the Electricity Regulatory Authority (ERA), and Government expects that power tariffs will begin to rise early in calendar 2012. Government understands that there is a trade-off between low power sector tariffs and higher budgetary subsidies, and is firmly committed to avoiding spending arrears on the latter. 
36. For the medium term, Government will need to implement the appropriate policy mix to balance demand for electricity with available financing and supply. The intention is to move to having ERA setting tariffs at cost recovery levels over the medium term. Moreover, the expected generation of power from the nearly completed Bujagali hydropower dam will reduce the power deficit and therefore reduce the need for subsidies. However, this will be short lived as demand will begin to exceed generation capacity about one and half years after the completion of Bujagali in April 2012. Government will include in the Budget Framework Paper for FY 2012/2013 a medium term strategic plan that will establish the timeframe over which power sector tariffs will move to cost recovery levels, and set out options for satisfying power sector demand in a cost-effective manner once demand outstrips the new power coming from the Bujagali hydropower project.

\section{Oil Revenue Management}

37. Government will provide for the prudent management and accountability of petroleum resources in the context of amendments to the PFAA. Our objective is to ensure that the necessary mechanisms for transparency and accountability are in place before large scale oil revenues begin to accrue. A dedicated account for oil revenues has been created in the Bank of Uganda on which capital gains tax has been deposited. Flows out of this account will only be made to the budget and for the near term will be used for financing the Karuma hydropower project. The amendments to the PFAA will legally establish the Petroleum Fund into which all oil and gas revenues will be deposited, and we will ensure that all spending is done through the budget. Government is considering the possibility of joining the Extractive Industries Transparency Initiative (EITI) in its commitment to transparency in oil revenue management. The reporting requirements in the proposed amendments to the PFAA will be designed to comply with the EITI requirements.

38. The BoU is to act as the investment manager for these resources on behalf of government, and will pursue an investment strategy that is - at least in the short runconsistent with its handling of Uganda's foreign exchange reserves. Until an Act of Parliament establishes the Fund, BoU is handling the payments of significant capital gains tax revenues consistent with these objectives. Looking to the medium term, the manner in which oil revenue will be managed must not compromise the growth and export potential of non-oil sectors in order to enhance employment creation in the country. This will entail building capacity in managing oil resources and also research capacity.

\section{Debt sustainability in the context of improved asset and liability management}

39. Government is currently updating the debt strategy to ensure continued debt sustainability in the context of accelerated public infrastructure investment. A key policy issue is to separate monetary policy instruments from the domestic financing of the deficit, by using secondary market operations for the former and primary securities issues for the latter. There is a need to enhance coordination between MoFPED and BoU on liquidity 
management, and also to develop capacity in MoFPED for debt management. In light of the intention to start accessing capital markets for infrastructure financing, Government requests technical assistance from the IMF on debt management.

40. Government recognizes that the most pressing constraint to stepped-up infrastructure investment is its own system of project assessment, planning, and implementation. Government intends to put in place an evaluation and appraisal criteria to ensure that all projects funded are economically and financially viable and consistent with the overall macroeconomic framework to ensure continued stability.

41. As we establish the legal framework for administering petroleum wealth through the amended PFAA, we will need to review our preparedness for asset management. The petroleum fund will be administered by the $\mathrm{BoU}$, but the investment guidelines and risk tolerance will be set by the government. In this regard, we also look forward to technical support from the IMF, insofar as asset and liability management must be viewed as a package.

\section{Program Monitoring}

42. Progress in the implementation of the policies under this program will be monitored through assessment criteria (ACs), indicative targets (IT), and structural benchmarks (SBs), detailed in the attached Tables 1 and 2 and through semi-annual reviews. Revised assessment criteria are added for end-December 2011 and proposed for end-June 2012, to be monitored respectively at the fourth and fifth reviews. The fourth review is expected to be completed by end-June 2012 and the fifth review by end-December 2012. The attached Technical Memorandum of Understanding - which is an integral part of this Memorandum - contains definitions and adjustors. During the program period, we will refrain from imposing or intensifying exchange restrictions as well as restrictions on imports for balance of payments reasons, or from introducing multiple currency practices. 
Table 1. Uganda: Proposed Quantitative Assessment Criteria and Indicative Targets for December 2011 - June 2012 1/

(Cumulative change from the beginning of the fiscal year, unless otherwise stated)

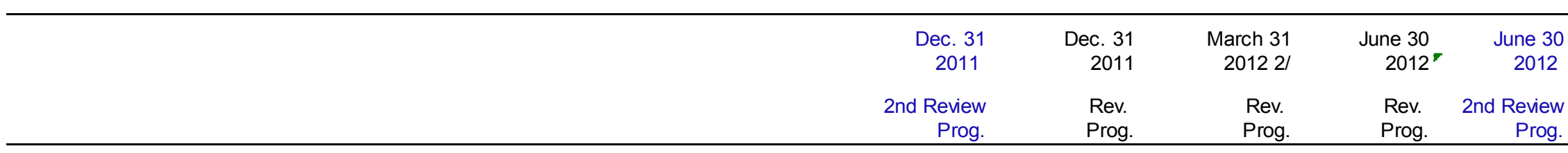

(Ush billions)

\section{Assessment criteria}

Ceiling on the increase in net domestic assets of the Bank of Uganda

\begin{tabular}{|c|c|c|c|c|}
\hline 877 & 652 & 830 & 892 & 1,150 \\
\hline 633 & 119 & 302 & 481 & 829 \\
\hline \multicolumn{5}{|c|}{ (US\$ millions) } \\
\hline 0 & 0 & 0 & 0 & 0 \\
\hline 800 & 800 & 800 & 800 & 800 \\
\hline 0 & 0 & 0 & 0 & 0 \\
\hline-121 & 309 & 282 & 300 & -51 \\
\hline 100 & 100 & 100 & 100 & 100 \\
\hline & \multicolumn{2}{|c|}{ (Ush billions) } & & \\
\hline 399 & 253 & 356 & 471 & 743 \\
\hline$\ldots$ & $\cdots$ & $\ldots$ & 0 & 50 \\
\hline 650 & $\cdots$ & $\ldots$ & 1,300 & 1,400 \\
\hline & 0 & 0 & 0 & \\
\hline
\end{tabular}

Ceiling on the stock of external payments arrears incurred by the public sector $3 /$

Ceiling on the contracting or guaranteeing of new nonconcessional external debt

with maturities greater than one year by the public sector $3 / 4 /$

Ceiling on new external debt with maturity up to one year contracted or guaranteed by the public sector $3 / 5 /$

Minimum increase in net international reserves of the Bank of Uganda

Share of oil revenue placed into Petroleum Fund (in percent) 政 


\begin{tabular}{|c|c|c|}
\hline \multicolumn{3}{|c|}{ Table 2. Uganda: Structural Benchmarks Under the PSI } \\
\hline Policy Measure & $\begin{array}{c}\text { Macroeconomic } \\
\text { Rationale }\end{array}$ & Date \\
\hline $\begin{array}{l}\text { Government to begin to gazette and publish } \\
\text { on the internet the names of beneficiaries } \\
\text { (whether individual or corporation) of all tax } \\
\text { expenditures (MEFP } \llbracket 5,24 \text { ). }\end{array}$ & $\begin{array}{l}\text { Enforce discipline in } \\
\text { issuance of tax } \\
\text { exemptions. }\end{array}$ & $\begin{array}{l}\text { September } 30,2011 \text {, and } \\
\text { quarterly thereafter }\end{array}$ \\
\hline $\begin{array}{l}\text { Begin submitting to Cabinet regular quarterly } \\
\text { reports on unpaid bills of nine Ministries } \\
\text { based on data in the Commitment Control } \\
\text { System (CCS) for the previous quarter of the } \\
\text { fiscal year (MEFP } \mathbb{4} 4,34 \text { ). }\end{array}$ & $\begin{array}{l}\text { To facilitate control and } \\
\text { elimination of expenditure } \\
\text { arrears }\end{array}$ & $\begin{array}{l}\text { June } 30,2011 \text {, for the } \\
\text { report covering Q3 of } \\
\text { FY2010/11, and quarterly } \\
\text { thereafter. }\end{array}$ \\
\hline $\begin{array}{l}\text { Produce and disseminate within government } \\
\text { a monthly index of economic activity relying } \\
\text { on the various high-frequency indicators } \\
\text { available (MEFP } ₫ 5,29) \text {. }\end{array}$ & $\begin{array}{l}\text { To facilitate the conduct } \\
\text { of monetary policy. }\end{array}$ & $\begin{array}{l}\text { September } 30,2011 \text {, and } \\
\text { quarterly thereafter. }\end{array}$ \\
\hline $\begin{array}{l}\text { BoU to include in Quarterly Report data on } \\
\text { the net and gross positions of government in } \\
\text { the BoU (MEFP } \llbracket 5 \text { ). }\end{array}$ & $\begin{array}{l}\text { Enhance central bank } \\
\text { independence and } \\
\text { prepare Bank of Uganda } \\
\text { to move toward inflation } \\
\text { targeting. }\end{array}$ & $\begin{array}{l}\text { September } 30,2011 \text {, and } \\
\text { quarterly thereafter. }\end{array}$ \\
\hline $\begin{array}{l}\text { Government to publish releases by MoFPED } \\
\text { for power and water obligations of spending } \\
\text { ministries, and actual payments by them, } \\
\text { with sanctions to be applied to the named } \\
\text { Accounting Officers of agencies that run } \\
\text { arrears on these utilities. (MEFP } \llbracket 33 \text { ). }\end{array}$ & $\begin{array}{l}\text { Help control accumulation } \\
\text { of arrears. Replaces } \\
\text { benchmark on "straight- } \\
\text { through payments" }\end{array}$ & $\begin{array}{l}\text { December } 15,2011 \text { (for } \\
\text { the previous quarter) and } \\
\text { quarterly thereafter. }\end{array}$ \\
\hline $\begin{array}{l}\text { Government to submit to Cabinet a strategy } \\
\text { to contain increases in power sector } \\
\text { subsidies, including establishing the } \\
\text { timeframe over which Energy Regulatory } \\
\text { Authority (ERA) is to move power tariffs to a } \\
\text { rules-based, cost-recovery level, and setting } \\
\text { out options for the period when power } \\
\text { demand outstrips the additional capacity } \\
\text { coming from Bujagali hydro project (MEFP } \\
\text { |36). }\end{array}$ & $\begin{array}{l}\text { Prevent accumulation of } \\
\text { expenditure arrears. }\end{array}$ & April 1, 2012. \\
\hline $\begin{array}{l}\text { Government to submit to Parliament a } \\
\text { supplementary budget to cover known } \\
\text { arrears and under-budgeted spending } \\
\text { obligations, including those for power sector } \\
\text { subsidies which may be required in light of } \\
\text { ERA's tariff setting policy. (MEFP \35). }\end{array}$ & $\begin{array}{l}\text { Prevent accumulation of } \\
\text { expenditure arrears }\end{array}$ & April 30, 2012. \\
\hline 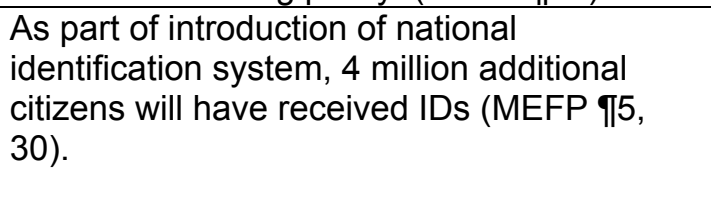 & $\begin{array}{l}\text { To support efforts to } \\
\text { strengthen revenue } \\
\text { collection and combat } \\
\text { money laundering and } \\
\text { the financing of terrorism. }\end{array}$ & June 30, 2012. \\
\hline
\end{tabular}




\section{Attachment II. Uganda: Technical Memorandum of Understanding}

\section{INTRODUCTION}

1. This memorandum defines the quarterly assessment criteria and indicative targets described in the memorandum of economic and financial policies (MEFP) for the period of December 31, 2011-June 30, 2012 financial program supported by the IMF Policy Support Instrument (PSI), and sets forth the reporting requirements under the instrument.

\section{Ceiling on the Cumulative InCRease in Net Domestic Assets (NDA) OF THE BANK OF UGANDA (BOU)}

2. Net foreign assets (NFA) of the BOU are defined as the monthly average (based on daily data) of foreign assets minus foreign liabilities, and include all foreign claims and liabilities of the central bank, excluding oil revenues in the petroleum fund. The monthly average values of all foreign assets and liabilities will be converted into U.S. dollars at each test date using the average cross exchange rates referred to in the table below for the various currencies and then converted into Uganda shillings using the program average U.S. dollarUganda shilling exchange rate for August 31, 2011.

\begin{tabular}{|l|r|}
\hline \multicolumn{2}{|c|}{ Program Exchange Rates } \\
\hline US dollar (US\$) & 1.0000 \\
\hline British pound/US\$ & 1.6282 \\
\hline US\$/Japanese yen & 76.4600 \\
\hline SDR/US\$ & 1.6094 \\
\hline US\$/Kenyan shillings & 93.8000 \\
\hline US\$/Tanzania shillings & $1,619.5000$ \\
\hline Euro/US\$ & 1.4398 \\
\hline US\$/Ugandan shillings & $2,821.1300$ \\
\hline
\end{tabular}

3. Net domestic assets (NDA) of the BoU are defined as the monthly average (based on daily data) of base money (defined below) less net foreign assets of the BoU (as defined in para. 2). Based on this definition, the NDA limits will be ceilings on the cumulative change from the monthly average based on daily data for June 2011 to the same monthly averages for December 2011, March and June 2012. 


\section{BASE MONEY}

4. Base money is defined as the sum of currency issued by BoU and the commercial banks' deposits in the BoU. The commercial bank deposits include the statutory required reserves and excess reserves held at the BoU and are net of the deposits of closed banks at the BoU and Development Finance Funds (DFF) contributed by commercial banks held at the BoU. The base money limits will be cumulative change from the monthly average based on daily data for June 2011 to the same monthly average for December 2011, and March and June 2012.

\section{Ceiling on the Cumulative Increase in Net Claims on the Central GOVERNMENT BY THE BANKING SYSTEM ${ }^{1}$}

5. Net claims on the central government by the banking system is defined as the difference between the outstanding amount of bank credits to the central government and the central government's deposits with the banking system, excluding oil revenues in the petroleum fund and deposits in administered accounts and project accounts with the banking system, including the central bank. Credits comprise bank loans and advances to the government and holdings of government securities and promissory notes. Central government's deposits with the banking system include the full amount of resources freed by the IMF MDRI. NCG by the banking system will be calculated based on data from balance sheets of the monetary authority and commercial banks as per the monetary survey.

\section{FloOr ON NEt International RESERVES OF THE BANK OF UgANDA}

6. Net international reserves (NIR) of the BoU are defined for program monitoring purpose as reserve assets of the BoU net of short-term external liabilities of the BoU. Reserve assets are defined as external assets readily available to, and controlled by, the BoU and exclude pledged or otherwise encumbered external assets, including, but not limited to, assets used as collateral or guarantees for third-party liabilities. Short-term external liabilities are defined as liabilities to nonresidents, of original maturities less than one year, contracted by the BoU and include outstanding IMF purchases and loans.

\section{FLOOR ON NET INTERNATIONAL RESERVES OF THE BANK OF UGANDA}

7. Net international reserves (NIR) of the BoU are defined for program monitoring purpose as reserve assets of the BoU net of short-term external liabilities of the BoU. Reserve assets are defined as external assets readily available to, and controlled by, the BoU and exclude pledged or otherwise encumbered external assets, including, but not limited to, assets used as collateral or guarantees for third-party liabilities. Short-term external liabilities are

\footnotetext{
${ }^{1}$ The central government comprises the treasury and line ministries.
} 
defined as liabilities to nonresidents, of original maturities less than one year, contracted by the BoU and include outstanding IMF purchases and loans.

8. For program-monitoring purposes, reserve assets and short-term liabilities at the end of each test period will be calculated in U.S. dollars by converting the stock from their original currency denomination at program exchange rates (as specified in paragraph 2).

\section{Ceiling on the Stock OF Domestic Budgetary ArRears of The Central GOVERNMENT}

9. The stock of domestic payment arrears/unpaid payment claims will be monitored on a quarterly basis. Domestic payments arrears/unpaid payment claims under the CCS are defined as the sum of all bills that have been received by a central government spending unit or line ministry delivered prior to the end of the quarter in question, and for which payment has not been made, under the recurrent expenditure budget (excluding court awards and pensions) or the development expenditure budget. For the purpose of program monitoring, the reports on domestic payment arrears/unpaid payment claims prepared by the Auditor General will be used to monitor this item following the end of the fiscal year. In the interim, the reports prepared by the Accountant General on unpaid claims will be monitored to gauge expenditure pressures.

\section{EXPENDITURES UNDER THE POVERTY ACTION Fund (PAF)}

10. The indicative target on expenditures under the Poverty Action Fund is designed to ensure that resources freed by debt relief are used for additional PAF expenditures. Compliance with the indicative floor for PAF expenditures will be verified on the basis of releases (PAF resources made available to spending agencies).

\section{CeIling ON ISSUANCE OF GuARANTEES BY THE GovernMENT OR BANK OF UGANDA}

11. The indicative target on issuance of guarantees by the Government or Bank of Uganda aims to prevent accumulation of contingent liabilities by the Government (including Government entities such as ministries, agencies and authorities). Included against the ceiling are any direct, contingent liabilities of Government (including entities that are part of government such as ministries, agencies and authorities) issued after June 30, 2011, and including any guarantees issued prior to July 1, 2011 but which are extended after June 30, 2011. This excludes guarantee programs which have explicit budget appropriations.

\section{Share of Oil Revenue Placed in Petroleum Fund}

12. The purpose of this assessment criterion is to avoid a situation whereby petroleum revenues bypass the Ugandan budget framework. A petroleum fund will be created upon passage of the revised Public Finance Act; in the meantime, government has established a petroleum revenue account in the Bank of Uganda. This QAC will be deemed satisfied if 
100 percent of petroleum revenues are transferred to this account upon collection by URA. These resources may then be spent or saved as governed by the organic budget law in force at the time (PFAA 2003 until the new PFA is enacted).

\section{AdJUSTERS}

13. The NDA and NIR targets are based on program assumptions regarding budget support, assistance provided under the Heavily Indebted Poor Countries (HIPC) Initiative and the Multilateral Debt Relief Initiative (MDRI), and external debt-service payments.

14. The NCG target for the banking system, in addition to being based on the aforementioned assumptions, is also based on assumptions regarding domestic nonbank financing of central government fiscal operations. In addition, the NDA target depends on the legal reserve requirements on deposits in commercial banks. Finally, the NDA and NIR targets are based on program assumptions regarding automatic access by commercial banks to the BOU's rediscount and discount window facilities.

15. The Uganda shilling equivalent of projected budget support (grants and loans) plus HIPC Initiative assistance in the form of grants on a cumulative basis from July 1 of the fiscal year is presented under Schedule A. The ceilings on the cumulative increase in NDA and NCG for the banking system will be adjusted downward (upward), and the floor on the cumulative increase in NIR of the BoU will be adjusted upward (downward) by the amount by which budget support, grants and loans, plus HIPC Initiative and MDRI assistance, exceeds (falls short of) the projected amounts.

\begin{tabular}{|l|r|r|r|r|}
\hline \multicolumn{5}{|c|}{$\begin{array}{c}\text { Schedule A: Budget Support (including HIPC and MDRI) } \\
\text { (Ush billions, cumulative from July 1, 2011) 1/ }\end{array}$} \\
\hline & September 30, 2011 & December 30, 2011 & March 31, 2012 & June 30, 2012 \\
\cline { 2 - 5 } Budget support, incl. HIPC and MDRI & & 415.8 & 942.3 & 1089.2 \\
\hline
\end{tabular}

16. The ceiling on the increases in NDA and NCG of the banking system will be adjusted downward (upward) and the floor on the increase in NIR will be adjusted upward (downward) by the amount by which debt service due ${ }^{2}$ plus payments of external debt arrears less deferred payments (exceptional financing) falls short of (exceeds) the projections presented in Schedule B. Deferred payments are defined to be (i) all debt service rescheduled under the HIPC Initiative; and (ii) payments falling due to all non-HIPC Initiative creditors that are not currently being serviced by the authorities (that is, gross new arrears being incurred).

\footnotetext{
${ }^{2}$ Debt service due is defined as pre-HIPC Initiative debt service due, excluding debt service subject to HIPC Initiative debt rescheduling.
} 


\begin{tabular}{|c|c|c|c|c|}
\hline \multicolumn{5}{|c|}{$\begin{array}{l}\text { Schedule B: External Debt Service } \\
\text { (Ush billions, cumulative from July 1, 2011) }\end{array}$} \\
\hline & September 30, 2011 & December 30, 2011 & March 31, 2012 & June 30,2012 \\
\hline $\begin{array}{l}\text { External debt service due before HIPC } \\
\text { excluding exceptional financing }\end{array}$ & 234.0 & 190.0 & 301.8 & 366.9 \\
\hline
\end{tabular}

17. The ceiling on increases in NCG of the banking system will be adjusted downward (upward) by any excess (shortfall) in nonbank financing, relative to the programmed cumulative amounts in Schedule C. Non-bank financing will include any domestic debteither in domestic currency or foreign currency - of the Government of Uganda that is held by creditors - whether resident or nonresident ${ }^{3}$ - that is not included in the Ugandan banking system. It will include the change in government securities held by the nonbank sector as reported in the monetary survey, as calculated by data provided by the Central Depository System (CDS), plus any other claims on government, including entities of government (ministries, agencies, authorities, etc.), held outside the banking system, including those which might be held by the National Social Security Fund (NSSF).

\begin{tabular}{|l|r|r|r|r|}
\hline \multicolumn{7}{|c|}{$\begin{array}{c}\text { Schedule C: Non-bank Financing } \\
\text { (Ush billions, cumulative from July 1, 2011) }\end{array}$} \\
\hline \multirow{3}{*}{ Nonbank financing } & September 30, 2011 & December 30, 2011 & March 31, 2012 & June 30, 2012 \\
\cline { 2 - 5 } & 208.0 & 511.2 & 361.2 & 124.2 \\
\hline
\end{tabular}

18. The floor on the cumulative increase in NIR of the BOU will be adjusted downward (upward) by the amount by which foreign exchange expenditures on the Karuma hydropower project exceeds (falls short of) the projected amounts as set out in Schedule D. The ceiling on NCG will be adjusted upward (downward) by the amount by which the domestic currency equivalent of Karuma spending (using the annual program exchange rate) exceeds the projected amounts as set out in Schedule D.

19. The ceiling on NDA of the BoU for every test date will be adjusted upward by the daily average amount of commercial bank automatic access to the BoU discount window and resdiscounting of government securities by commercial banks.

20. The ceiling on NDA of the BoU for every test date will be adjusted downward/upward to reflect decreases/increases in the legal reserve requirements on deposits in commercial banks. The adjuster will be calculated as the percent changes in the reserve requirement multiplied by the actual amount of required reserves (Uganda shillings and foreign-currency denominated) at the end of the previous calendar month.

\footnotetext{
${ }^{3}$ Non-residents holding government securities are excluded from the definition of external debt in paragraph 20.
} 


\begin{tabular}{|l|r|r|r|r|}
\hline \multicolumn{5}{|c|}{$\begin{array}{c}\text { Schedule D: Expenditures for Karuma hydropower project } \\
\text { (US\$ millions, cumulative from July 1, 2011) }\end{array}$} \\
\hline \multirow{2}{*}{$\begin{array}{l}\text { Foreign exchange expenditures } \\
\text { for Karuma hydropower project }\end{array}$} & September 30, 2011 & December 30, 2011 & March 31, 2012 & June 30, 2012 \\
\cline { 2 - 5 } & 0.0 & 0.0 & 150.0 & 150.0 \\
\hline
\end{tabular}

\section{Ceiling on the Contracting OR Guaranteeing OF New Nonconcessional External Debt by the Public Sector, and Ceiling on the Stock of External Payments Arrears Incurred by the Public SeCtor ${ }^{4}$}

21. The assessment criterion on short-term debt refers to contracting or guaranteeing external debt with original maturity of one year or less by the public sector. Excluded from this assessment criterion are normal import-related credits and non-resident holdings of government securities and government promissory notes. The definition of "debt" is set out in paragraph 19.

22. The program includes a ceiling on new nonconcessional borrowing with maturities greater than one year contracted or guaranteed by the public sector. ${ }^{5}$ Nonconcessional borrowing is defined as loans with a grant element of less than 35 percent, calculated using average commercial interest rates references (CIRRs) published by the Organization for Economic Cooperation and Development (OECD). In assessing the level of concessionality, the 10-year average CIRRs should be used to discount loans with maturities of at least 15 years, while the 6-month average CIRRs should be used for loans with shorter maturities. To both the 10-year and 6-month averages, the following margins for differing payment periods should be added: 0.75 percent for repayment periods of less than 15 years; 1 percent for 15-19 years; 1.15 percent for 20-25 years; and 1.25 percent for 30 years or more. The ceiling on nonconcessional external borrowing or guarantees is to be observed on a continuous basis. The coverage of borrowing includes financial leases and other instruments giving rise to external liabilities, not only current as defined below, but also contingent, on nonconcessional terms. External debt for the purpose of this assessment criterion means borrowing giving rise to liabilities to non-residents. Excluded from the limits are changes in indebtedness resulting from non-resident holdings of government securities and government promissory notes, refinancing credits and rescheduling operations, and credits extended by the IMF. For the purposes of the program, arrangements to pay over time obligations arising from judicial awards to external creditors that have not participated in the HIPC Initiative do

\footnotetext{
${ }^{4}$ Public sector comprises the general government (which includes the central government, local governments, and monetary authorities), and entities that are public corporations which are subject to 'control by the government', defined as the ability to determine general corporate policy or by at least 50 percent government ownership.

${ }^{5}$ Contracting and guaranteeing is defined as approval by a resolution of Parliament as required in Section 20(3) and 25(3) of the Public Finance and Accountability Act, 2003
} 
not constitute nonconcessional external borrowing. Excluded from these limits are also nonconcessional borrowing within the limits specified in Table 1 of the MEFP. The ceiling also excludes nonconcessional borrowing by one state-owned bank, Housing Finance Bank, which poses limited fiscal risk and is in a position to borrow without a government guarantee.

23. The definition of debt, for the purposes of the limit, is set out in point 9 of the Guidelines on Performance Criteria with Respect to External Debt (Executive Board's Decision No. 6230-(79/140), as amended by Decision No 14416-(09/91, effective December 1, 2009). It not only applies to the debt as defined in Point 9 of the Executive Board decision, but also to commitments contracted or guaranteed for which value has not been received. The definition of debt set forth in No. 9 of the Guidelines on Performance Criteria with Respect to External Debt in Fund Arrangements reads as follows:

(a) For the purpose of this guideline, the term "debt" will be understood to mean a current, i.e., not contingent, liability, created under a contractual arrangement through the provision of value in the form of assets (including currency) or services, and which requires the obligor to make one or more payments in the form of assets (including currency) or services, at some future point(s) in time; these payments will discharge the principal and/or interest liabilities incurred under the contract. Debts can take a number of forms, the primary ones being as follows: (i) loans, i.e., advances of money to the obligor by the lender made on the basis of an undertaking that the obligor will repay the funds in the future (including deposits, bonds, debentures, commercial loans and buyers' credits) and temporary exchanges of assets that are equivalent to fully collateralized loans under which the obligor is required to repay the funds, and usually pay interest, by repurchasing the collateral from the buyer in the future (such as repurchase agreements and official swap arrangements); (ii) suppliers' credits, i.e., contracts where the supplier permits the obligor to defer payments until some time after the date on which the goods are delivered or services are provided; and (iii) leases, i.e., arrangements under which property is provided which the lessee has the right to use for one or more specified period(s) of time that are usually shorter than the total expected service life of the property, while the lesser retains the title to the property. For the purpose of the guideline, the debt is the present value (at the inception of the lease) of all lease payments expected to be made during the period of the agreement excluding those payments that cover the operation, repair, or maintenance of the property. (b) Under the definition of debt set out in point 9(a) above, arrears, penalties, and judicially awarded damages arising from the failure to make payment under a contractual obligation that constitutes debt. Failure to make payment on an obligation that is not considered debt under this definition (e.g., payment on delivery) will not give rise to debt. 
24. The ceiling on the accumulation of new external payments arrears is zero. This limit, which is to be observed on a continuous basis, applies to the change in the stock of overdue payments on debt contracted or guaranteed by the public sector from their level at end-June 2006. External debt payment arrears consist of external debt service obligations (reported by the Statistics Department of the BOU, the Macro Department of the Ministry of Finance) that have not been paid at the time they are due as specified in the contractual agreements but shall exclude arrears on obligations subject to rescheduling.

\section{MONITORING AND REPORTING REQUIREMENTS}

25. The Government of Uganda will submit information to IMF staff with the frequency and submission time lag as indicated in Table 1 . The quality and timeliness of the data submission will be tracked and reported by IMF staff. The information should be mailed electronically to AFRUGA@IMF.ORG. 


\begin{tabular}{|c|c|c|c|}
\hline \multicolumn{4}{|c|}{ Attachment II. Table 1. Summary of Reporting Requirements } \\
\hline $\begin{array}{l}\text { Reporting } \\
\text { institution }\end{array}$ & Report/Table & $\begin{array}{l}\text { Submission } \\
\text { Frequency }\end{array}$ & Submission lag \\
\hline \multirow[t]{12}{*}{$\begin{array}{l}\text { I. Bank of } \\
\text { Uganda }\end{array}$} & $\begin{array}{l}\text { Issuance of government securities, repurchase } \\
\text { operations and reverse repurchase operations }\end{array}$ & Weekly & 5 working days \\
\hline & Operations in the foreign exchange & Weekly & 5 working days \\
\hline & $\begin{array}{l}\text { Interest rates ( } 7 \text { day interbank, commercial bank } \\
\text { prime lending rate, government securities) }\end{array}$ & Weekly & 5 working days \\
\hline & $\begin{array}{l}\text { Private sector credit growth by shilling and forex, and } \\
\text { excess reserves of commercial banks }\end{array}$ & Weekly & 5 working days \\
\hline & Disaggregated consumer price index. & Monthly & 2 weeks \\
\hline & $\begin{array}{l}\text { Balance sheet of the BOU, consolidated accounts of } \\
\text { the commercial banks, and monetary survey. }\end{array}$ & Monthly & 4 weeks \\
\hline & Monthly foreign exchange cash flow table of BOU. & quarterly & 4 weeks \\
\hline & $\begin{array}{l}\text { Statement of (i) cash balances held in project } \\
\text { accounts at commercial banks; (ii) total value } \\
\text { (measured at issue price) of outstanding government } \\
\text { securities from the Central Depository System (CDS); } \\
\text { and (iii) the stock of government securities (measured } \\
\text { at issue price) held by commercial banks from the } \\
\text { CDS. }\end{array}$ & Quarterly & 6 weeks \\
\hline & $\begin{array}{l}\text { Summary of (i) monthly commodity and direction of } \\
\text { trade statistics; (ii) disbursements, principal and } \\
\text { interest, flows of debt rescheduling and debt } \\
\text { cancellation, arrears, and committed undisbursed } \\
\text { balances-by creditor category; and (iii) composition } \\
\text { of nominal HIPC Initiative assistance. }\end{array}$ & Quarterly & 6 weeks \\
\hline & $\begin{array}{l}\text { Summary of stock of external debt, external arrears, } \\
\text { and committed undisbursed loan balances by creditor. }\end{array}$ & Quarterly & 6 weeks \\
\hline & $\begin{array}{l}\text { Standard off-site bank supervision indicators for } \\
\text { deposit money banks. }\end{array}$ & Quarterly & 4 weeks \\
\hline & $\begin{array}{l}\text { Summary table of preliminary program performance } \\
\text { comparing actual outcome with adjusted program } \\
\text { targets for (i) base money; (ii) net claims on central } \\
\text { government by the banking system; ( (iv) new } \\
\text { nonconcessional external borrowing; and (v) net } \\
\text { international reserves }\end{array}$ & Quarterly & 6 weeks \\
\hline
\end{tabular}




\begin{tabular}{|c|c|c|c|}
\hline \multicolumn{4}{|c|}{ Attachment II. Table 1. Summary of Reporting Requirements (concluded) } \\
\hline $\begin{array}{l}\text { Reporting } \\
\text { institution }\end{array}$ & Report/Table & Frequency & $\begin{array}{l}\text { Submissi } \\
\text { on lag }\end{array}$ \\
\hline \multirow[t]{7}{*}{$\begin{array}{l}\text { II. Ministry of } \\
\text { Finance }\end{array}$} & $\begin{array}{l}\text { Summary of central government accounts. Revenues } \\
\text { shall be recorded on a cash basis. Expenditures shall be } \\
\text { recorded when checks are issued, except for domestic } \\
\text { and external debt-service payments, cash transfers to } \\
\text { districts, and externally funded development } \\
\text { expenditures. Expenditures on domestic interest will be } \\
\text { recorded on an accrual basis and external debt service } \\
\text { will be recorded on a commitment basis (i.e., when } \\
\text { payment is due). }\end{array}$ & Monthly & 4 weeks \\
\hline & $\begin{array}{l}\text { Summary of outstanding stock of unpaid payment } \\
\text { claims }\end{array}$ & Quarterly & 6 weeks \\
\hline & $\begin{array}{l}\text { Summary of contingent liabilities of the central } \\
\text { government and the Bank of Uganda. For the purpose } \\
\text { of the program, contingent liabilities include all } \\
\text { borrowings by statutory bodies, government guarantees, } \\
\text { claims against the government in court cases that are } \\
\text { pending, or court awards that the government has } \\
\text { appealed. }\end{array}$ & Quarterly & 6 weeks \\
\hline & $\begin{array}{l}\text { Detailed monthly central government account of } \\
\text { disbursed budget support and project grants and loans } \\
\text { (less change in the stock of project accounts held at the } \\
\text { BoU and commercial banks), HIPC support, and } \\
\text { external debt service due and paid. }\end{array}$ & Quarterly & 4 weeks \\
\hline & $\begin{array}{l}\text { Detailed central government account of disbursed donor } \\
\text { project support grants and loans. }\end{array}$ & Monthly & 6 weeks \\
\hline & $\begin{array}{l}\text { Statement on new external loans contracted or } \\
\text { guaranteed by the central government and the Bank of } \\
\text { Uganda during the period according to loan agreements. }\end{array}$ & Quarterly & 6 weeks \\
\hline & $\begin{array}{l}\text { Updated national accounts statistics (real and nominal) } \\
\text { according to UBOS and medium-term projections. }\end{array}$ & Quarterly & 12 weeks \\
\hline
\end{tabular}




\section{INTERNATIONAL MONETARY FUND}

UGANDA

Third Review Under the Policy Support Instrument, Request for Waiver of Nonobservance of an Assessment Criterion, and Request for Modification of Assessment Criteria-Informational Annex

Prepared by the African Department

(In consultation with other departments)

December 20, 2011

- $\quad$ Relations with the Fund. Describes financial and technical assistance by the IMF and provides information on the safeguards assessment and exchange system. Outstanding Fund credit was SDR 4.8 million (2.66 percent of quota) as of at end-October, 2011.

- Joint Bank-Fund Work Program. Describes Bank-Fund collaboration from July 2011 to June 2012.

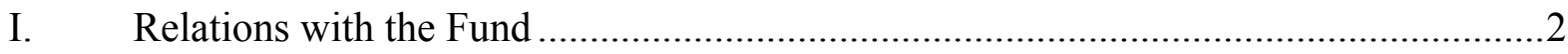

II. Joint Bank-Fund Work Program, July 2011-June 2012 ......................................6 


\section{APPENDiX I. UgANDA: Relations With THE FUND}

(As of October 31, 2010)

I. Membership Status: Joined: September 27, 1963;

Article VIII

II. General Resources Account:

SDR Million

\%Quota

Quota

180.50

100.00

Fund holdings of currency

180.51

100.00

III. SDR Department:

SDR Million

\%Allocation

Net cumulative allocation

173.06

100.00

Holdings

142.27

82.21

IV. Outstanding Purchases and Loans:

SDR Million

\%Quota

ECF Arrangements

4.80

2.66

V. Latest Financial Arrangements:

\begin{tabular}{|c|c|c|c|c|}
\hline Type & $\begin{array}{c}\text { Date of } \\
\text { Arrangement }\end{array}$ & $\begin{array}{c}\text { Expiration } \\
\text { Date }\end{array}$ & $\begin{array}{c}\text { Amount Approved } \\
\text { (SDR Million) }\end{array}$ & $\begin{array}{l}\text { Amount Drawn } \\
\text { (SDR Million) }\end{array}$ \\
\hline $\mathrm{ECF}$ & Sep 13,2002 & $\operatorname{Jan} 31,2006$ & 13.50 & 13.50 \\
\hline $\mathrm{ECF}^{1}$ & Nov 10, 1997 & Mar 31, 2001 & 100.43 & 100.43 \\
\hline $\mathrm{ECF}^{1}$ & Sep 06, 1994 & Nov 09, 1997 & 120.51 & 120.51 \\
\hline
\end{tabular}

VI. Projected Payments to Fund ${ }^{16}$

(SDR Million; based on existing use of resources and present holdings of SDRs):

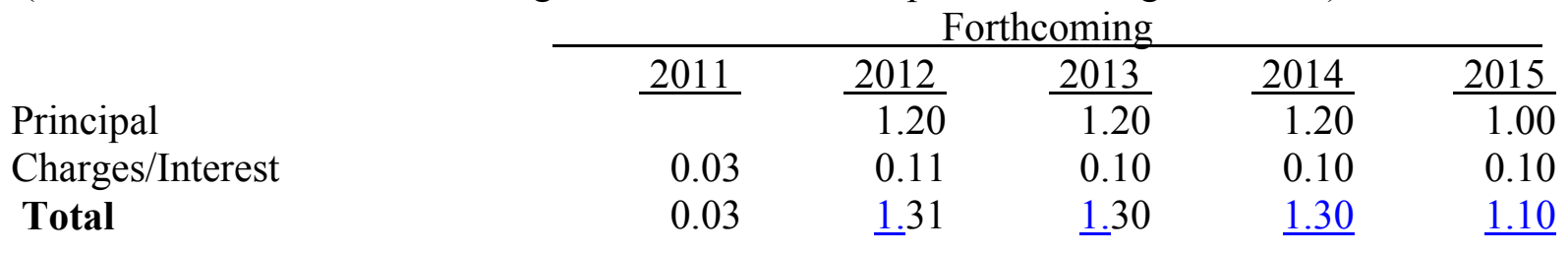

\section{Implementation of HIPC Initiative:}

I. Commitment of HIPC assistance

Original Enhanced

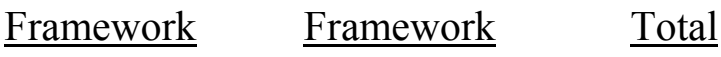

\footnotetext{
${ }^{15}$ Formerly PRGF.

${ }^{16}$ When a member has overdue financial obligations outstanding for more than three months, the amount of such arrears will be shown in this section.

${ }^{3}$ Assistance committed under the original framework is expressed in net present value (NPV) terms at the completion point, and assistance committed under the enhanced framework is expressed in NPV terms at the decision point. Hence these two amounts cannot be added.
} 
Decision point date

Apr 1997

Feb 2000

Assistance committed

by all creditors (US\$ Million) ${ }^{17}$

347.00

656.00

Of which: IMF assistance (US\$ million)

68.90

91.00

(SDR equivalent in millions)

51.51

68.10

Completion point date

Apr 1998

May 2000

II. Disbursement of IMF assistance (SDR Million)

Assistance disbursed to the member

51.51

68.10

119.61

Interim assistance

$--$

8.20

8.20

Completion point balance

51.51

59.90

111.41

Additional disbursement of interest income ${ }^{18}$

Total disbursements

51.51

2.06

2.06

70.16

121.67

\section{Implementation of Multilateral Debt Relief Initiative (MDRI):}

I. MDRI-eligible debt (SDR Million) ${ }^{19}$

87.73

Financed by: MDRI Trust

75.85

Remaining HIPC resources

II. Debt Relief by Facility (SDR Million)

Eligible Debt

$\begin{array}{rrrr}\frac{\text { Delivery }}{\text { Date }} & \frac{\text { GRA }}{\mathrm{N} / \mathrm{A}} & \frac{\text { PRGF }}{87.73} & \frac{\text { Total }}{87.73}\end{array}$

\footnotetext{
${ }^{18}$ Under the enhanced framework, an additional disbursement is made at the completion point corresponding to interest income earned on the amount committed at the decision point but not disbursed during the interim period.

${ }^{19}$ The MDRI provides 100 percent debt relief to eligible member countries that qualified for the assistance. Grant assistance from the MDRI Trust and HIPC resources provide debt relief to cover the full stock of debt owed to the Fund as of end-2004 that remains outstanding at the time the member qualifies for such debt relief.
} 


\section{Safeguards Assessments}

Under the Fund's safeguards policy, assessments with respect to the PSI are voluntary. An update assessment of the Bank of Uganda (BOU) was completed on April 10, 2007 and concluded that the BOU had strengthened its safeguards framework since the 2003 assessment. The main developments included implementation of International Financial Reporting Standards, publication of financial statements, establishment of an audit committee, and strengthening of the internal audit function. Staff made recommendations to address remaining vulnerabilities in the legal and internal control areas.

\section{Exchange Rate Arrangement}

The official exchange rate is determined on the interbank market for foreign exchange. As of end-October, 2011 the official exchange rate was USh 2805-- per U.S. dollar. The exchange system is free of restrictions on the making of payments and transfers for current international transactions. Uganda's exchange rate regime is classified as floating.

\section{Article IV Consultation}

The Executive Board concluded the last Article IV consultation on February 11, 2011. The next Article IV consultation with Uganda will be held on the 24-month cycle, subject to the provisions of the decision on consultation cycles approved on September 28, 2010.

In February and April 2001, joint World Bank/Fund missions visited Kampala as part of the Financial Sector Assessment Program (FSAP). A final report was provided to the authorities in November 2001, and an MFD mission discussed the report with the authorities during the Article IV consultation discussion in November 2002; the Financial System Stability Assessment was prepared for Board discussion in February 2003. In November 2004, a joint World Bank/Fund missions visited Kampala for a FSAP update. At the request of the authorities, a new FSAP update mission was Kampala in August, 2011; a Financial System Stability Assessment - Update (FSSA Update) is to be considered by the Executive Board together with this review, which would then complete a set of FSAP updates for all five EAC members.

\section{Policy Support Instrument (PSI)}

The Executive Board approved a new three-year Policy Support Instrument (PSI) and completed the seventh and final review under the previous PSI on May 12, 2010. The new PSI follows on the first three-year PSI, which was approved in December 2006 and extended by one year in 2009, then concluded successfully in May 2010. 


\section{Technical Assistance}

Uganda has received extensive technical assistance from the Fund in recent years. ${ }^{20}$

The Fiscal Affairs Department (FAD) has provided several TA mission in recent years. In March 2011, a tax policy mission helped the authorities identify possible reforms to improve the buoyancy and efficiency of the domestic tax system. In July, another TA mission provided strategic direction for the next major phase of modernization for the Uganda Revenue Authority. Last August, a TA public financial management mission assisted the authorities in the redrafting of a new Uganda Public Finance Act in a follow-up to the November 2010 TA mission on the modernization of Uganda's legislation in this area; discussions also covered the fiscal aspects of the management of prospective oil revenues. The aim would be to provide capacity building in forecasting government oil revenues and modeling the macroeconomic implications of alternative fiscal anchors.

A TA mission on enhancing the effectiveness of monetary policy implementation and developing financial markets was conducted in August 2005; in April 2006 MCM and the BOU held a joint workshop on financial market development. In recent years MCM has provided follow up TA to strengthen capacity to undertake financial stability analysis and reporting; and in $2011 \mathrm{MCM}$ has provided additional TA to help the BOU revise the monetary policy framework and strengthen its capacity in monetary analysis and operations. In June 2011, MCM conducted a multi-topic technical assistance mission to help authorities enhance the central bank capacity in the areas of monetary operations and central bank accounting.

\section{Future Technical Assistance Priorities}

The priorities for Fund technical assistance in the next few years will be in the areas of tax administration and tax policy reforms, oil revenue management, public expenditure management, especially control and monitoring of government arrears, monetary and exchange rate management, bank supervision, national accounts statistics, reporting standards for government finance statistics, monetary and balance of payments statistical reporting, central bank accounting, and audit and debt management.

\section{Resident Representative}

The Fund has maintained a resident representative in Uganda since July 1982.

\footnotetext{
${ }^{20}$ For a description of technical assistance provided prior to 2006, see the staff report for Uganda's request for a three-year PSI (IMF Country Report No. 06/43).
} 
ApPendix II. Joint BAnk-Fund WORK Program, July 2011 - June 2012

\begin{tabular}{|c|c|c|c|}
\hline Title & Products & $\begin{array}{l}\text { Provisional } \\
\text { timing of } \\
\text { missions (if } \\
\text { relevant) } \\
\end{array}$ & $\begin{array}{l}\text { Expected } \\
\text { delivery date }\end{array}$ \\
\hline \multirow[t]{5}{*}{$\begin{array}{l}\text { 1. World Bank } \\
\text { Work Program }\end{array}$} & $\begin{array}{l}\text { The work program will continue to } \\
\text { concentrate on areas within the existing } \\
\text { portfolio, including infrastructure } \\
\text { development (transport and energy), } \\
\text { secondary education, health infrastructure, } \\
\text { agricultural research, advisory services } \\
\text { and training, Kampala infrastructure } \\
\text { development, and local government } \\
\text { service delivery (including Northern } \\
\text { Uganda rehabilitation). In addition, the } \\
\text { Bank project to support public service } \\
\text { performance enhancement, Northern } \\
\text { Uganda social protection, minerals } \\
\text { development and environment } \\
\text { sustainability will be maintained. }\end{array}$ & & \\
\hline & $\begin{array}{l}\text { Policy Note "Strategic Review of the } \\
\text { Electricity Sector" }\end{array}$ & $\begin{array}{l}\text { September- } \\
\text { October } 2011\end{array}$ & $\begin{array}{l}\text { Draft delivered } \\
\text { Nov. } 2011 \\
\text { Final: January } \\
2012\end{array}$ \\
\hline & $\begin{array}{l}\text { Ninth Poverty Reduction Support Credit - } \\
\text { focus on enhancing effectiveness of } \\
\text { service delivery, public sector } \\
\text { management, and human development } \\
\text { issues. }\end{array}$ & & February 2012 \\
\hline & $\begin{array}{l}\text { Public Expenditure Review (2012) with a } \\
\text { focus on decentralization and delivery of } \\
\text { social services. }\end{array}$ & $\begin{array}{l}\text { Jan-Mar } \\
2012\end{array}$ & $\begin{array}{l}\text { Draft report: } \\
\text { June } 2012\end{array}$ \\
\hline & $\begin{array}{l}\text { Study on shared/spatial growth with } \\
\text { special focus on agriculture, labor and } \\
\text { integration of leading and lagging areas. }\end{array}$ & June 2010 & $\begin{array}{l}\text { Delivered, } \\
\text { November } \\
2011\end{array}$ \\
\hline
\end{tabular}




\begin{tabular}{|c|c|c|c|}
\hline \multirow[t]{3}{*}{$\begin{array}{l}\text { 2. Fund Work } \\
\text { Program }\end{array}$} & $\begin{array}{l}\text { Third Review under the PSI. Program } \\
\text { emphasis: fiscal space for high value } \\
\text { added infrastructure investment, enhanced } \\
\text { revenues, better PFM and budget, } \\
\text { coherency of monetary and fiscal policies, } \\
\text { preparation for market access and oil } \\
\text { revenues. }\end{array}$ & October 2011 & $\begin{array}{l}\text { December } \\
2011\end{array}$ \\
\hline & $\begin{array}{l}\text { Fourth Review under the PSI: } \\
\text { As above }\end{array}$ & March 2012 & June 2012 \\
\hline & $\begin{array}{l}\text { TA priorities: } \\
\text { revision of PFAA: } \\
\text { monetary policy and transition to } \\
\text { inflation targeting; } \\
\text { revenue enhancement, including } \\
\text { tax policy follow-up and revenue } \\
\text { administration; } \\
\text { - } \\
\text { Asset and debt management } \\
\text { (including petroleum revenue } \\
\text { management) } \\
\text { Enhancing macroeconomic } \\
\text { statistics, including national } \\
\text { accounts, BoP data, and GFS. }\end{array}$ & TBD & TBD \\
\hline \multirow{3}{*}{$\begin{array}{l}\text { 3. Joint Work } \\
\text { Program }\end{array}$} & JSAN on the Midterm NDP Review. & March 2012 & June 2012 \\
\hline & Joint FSAP & August 2011 & $\begin{array}{l}\text { December } \\
2011\end{array}$ \\
\hline & Joint DSA update & March 2012 & June 2012 \\
\hline
\end{tabular}


Press Release No. 12/8

International Monetary Fund

FOR IMMEDIATE RELEASE

Washington, D.C. 20431 USA

January 13, 2012

\section{IMF Executive Board Completes Third Review Under Policy Support Instrument for Uganda}

The Executive Board of the International Monetary Fund (IMF) today completed the third review under the Policy Support Instrument (PSI) for Uganda. In completing the review, the Board approved a waiver of nonobservance of the ceiling on net credit to government and the modification of quantitative assessment criteria.

The PSI for Uganda was approved on May 12, 2010 (see Press Release No. 10/195) and aims at maintaining macroeconomic stability and alleviating constraints to growth. The IMF's framework for PSIs is designed for low-income countries that may not need, or want, IMF financial assistance, but still seek IMF advice, monitoring and endorsement of their policies. PSIs are voluntary and demand driven (see Public Information Notice No. 05/145).

Following the Executive Board's discussion on Uganda, Mr. Naoyuki Shinohara, Deputy Managing Director and Acting Chair, stated:

"The Ugandan authorities have appropriately tightened monetary policy to help reverse the acceleration in inflation over the past nine months, in light of increasing evidence that external events have spilled over into underlying domestic inflation. Restrained fiscal policy will support disinflation efforts. The tighter policy stance should facilitate a rebuilding of international reserves and reduce exchange rate volatility. Given higher interest rates and inflation, the Bank of Uganda will also reinforce financial sector supervision.

"Growth is likely to slow in 2012 in light of tighter policies combined with a weaker global growth outlook. However, rapid disinflation is critical to restore the stable macroeconomic environment that has been a necessary foundation for Uganda's strong and inclusive growth over the past decade.

"Subsidies to the power sector have grown quite large and consume resources urgently needed to implement Uganda's National Development Plan. The authorities have announced 
a significant increase in tariffs, which will contain subsidy costs this fiscal year. For the future, they are committed to establishing a system to adjust tariffs automatically in line with changes in underlying costs.

"Over the medium term, the authorities plan to bring their revenue effort in line with other East African countries, mainly by eliminating tax exemptions and incentives. They are also taking steps to put in place a more robust budget management system, including a prudent petroleum revenue management framework", Mr. Shinohara added. 


\section{Statement by Mr. Majoro, Executive Director for Uganda January 13, 2012}

1. My Ugandan authorities remain determined to persevere with prudent macroeconomic policies in the face of a second round of heightened global economic uncertainty coupled with continued regional demand shocks and structural supply constraints for food. Growth has tapered off, the exchange rate has gone through a volatile period and inflation has spiked. The authorities are, in this regard, determined to deepen structural reforms and strengthen the EAC regional integration framework to protect the economy from a deeper downturn and also to sustain macroeconomic stability. With their policy stance and continued support from the international community and policy guidance from the Fund, my authorities are confident that they stand a good chance of mitigating the headwinds emanating from the current protracted round of commodity price surges and the fallout from the sovereign debt risks in advanced economies. That support would also help them manage the increasingly challenging policy environment. To that end, they are committed to strengthen the implementation of their program under the PSI and to fully restore the track record of macroeconomic stability attained over the years.

2. My authorities are appreciative of the Fund's constructive engagement and support under the PSI and the enhanced levels of technical assistance packages also in view of the new oil economy. Going forward, they are determined to further strengthen their macroeconomic framework, and achieve key national and regional objectives set out in their National Development Plan (NDP) and East African single market protocols that are supported by the PSI.

3. To that end, and in view of the strong performance under the program - with all but one of the end-June 2011 quantitative performance/assessment criteria observed with good margins, and implementation of structural reforms generally on track - they request Directors' support for the completion of the third review of the PSI. They also request Director's support for the waiver for the nonobservance of the quantitative assessment criteria-the net credit to government (NCG) - and agree with staff's recommendation for the establishment of the end-December 2011 and end-June 2012 targets.

\section{Recent economic developments and respective policy environment}

4. While Uganda's strengthened economic fundamentals over the years - policy-wise and the broadened economic base - helped the country weather the storm of the global economic downturn and a swift return to a growth path, continued global economic uncertainties and regional specific shocks has generated new sets of challenges. Real GDP growth that had recovered from 5.2 percent in 2009 to 6.7 percent in 2010/2011 is now under threat, projected to decline to 5.0 percent, mainly due to the deterioration in the external environment and the tight macroeconomic stance to curb inflation. However, stronger investment in agriculture, power and roads, the coming into stream of the new oil and gas 
economy, and restoration of macroeconomic stability are expected to support growth in the medium term.

5. The repetitive regional drought conditions, the protracted high global food and fuel prices and the recent exchange rate volatility continue to exert considerable pressure on domestic inflation. My authorities recognize that monetary factors have also played a role, with growth of private sector credit at 44 percent over the past year. They are, in this regard, strengthening their monetary and fiscal policy frameworks, also in line with staff recommendations, to significantly reduce core inflation. To that end, the central bank of Uganda (BoU) adopted a tighter monetary policy stance and will continue with its disinflation path going forward. In addition, my authorities have introduced a benchmark central bank rate (CBR) in tandem with BoU's new inflation targeting lite (ITL) aimed at strengthening the monetary policy framework. Though it may be too early to judge the efficacy of the tightening of monetary policy on inflation and private sector credit growth, the authorities are mindful of the fact that the current disinflation policy stance will have an adverse impact on growth in the short run. They are also mindful that higher interest rates, lower growth and exchange rate volatility could put pressure on banks' asset quality. They, however, view this policy framework as essential to control inflation and protect their longer term growth and poverty reduction objectives. They also count on the continued strengthening of the banking system, building on the high degree of resilience as evidenced by the recent FSAP update.

6. External balances weakened significantly in FY 2010/11 and the external deficit is expected to remain high in the medium term in view of the rising investment in infrastructure including large-scale investments in power generation and in the oil sector. The current account deficit (including grants) is estimated to have worsened to 12.9 percent of GDP from 9.6 percent in FY2009/10. This is on account of the limited growth in exports due to weaker demand, coupled with strong imports, both in volume and value terms, particularly for oil, construction services and large security related purchases, and sales of foreign exchange to contain the shilling volatility. As a result, international reserves declined to 3.3 months of imports cover by end-June 2011 from a high of 5.1 months in FY2008/09.

7. My authorities' fiscal policy has remained on the consolidation stance. In line with this policy stance, the authorities have resisted domestic pressure this year to increase public sector wages as a result of high inflation, and they intend to maintain nominal spending broadly in line with the FY2011/12 budget, resulting in a large real spending contraction. Though recurrent spending accommodates power sector subsidies, the authorities have agreed on the need to develop a strategy that will include, inter alia, periodic tariff adjustments, to reduce further power sector subsidies. The authorities' fiscal policy stance implies that, on the overall, the fiscal framework has remained within the PSI targets. 


\section{Medium-term policy framework and reforms}

\section{Fiscal policy and related reforms}

8. My authorities' fiscal policy will strive to strike and maintain an appropriate balance between the objective of addressing the challenges of rising inflation and those of sustaining the growth momentum including meeting the challenges of unemployment and deficits in infrastructure and social service delivery. To achieve these objectives, the authorities intend to restructure the budget to refocus it to the medium term priorities with the view of creating sufficient fiscal space that would sustain budgetary spending levels for the priority services, and modest scaling-up of investment in infrastructure and primary sectors to shore-up economic growth. Structural reforms of the budgetary process to improve budget execution and efficiency will continue to be prioritized.

9. To maintain prudent spending in the priority areas while maintaining a fiscal consolidation path, the authorities will continue to strengthen domestic and concessional resource mobilization in the medium term. On the revenue front, the authorities have made an undertaking to enhance revenue reforms in line with staff recommendations with the view of raising the revenue yield. The scope of tax expenditures, exemptions and holidays will be streamlined to boost domestic revenue collections. To enhance compliance, they are implementing a phased roll-out of e-tax services across the country. Cognizant of the overall capacity limitations, they intend to request additional TA from the Fund in this area.

10. On the expenditure side, the authorities will pursue expenditure streamlining in line with the program while maintaining a clear focus on the priorities of their National Development Plan especially on road and energy infrastructure paralleled by prudent spending on the MDG clusters to boost growth and reduce poverty. Additionally, they will enhance the steps taken to strengthen budget execution, and also will strive to improve the alignment between policy objectives and the budget through prioritization of public investment in line with their NDP.

11. To improve budget execution and efficiency, the authorities are intending to submit to Parliament a comprehensively reviewed Public Finance Accountability Act (PFAA) that will, inter alia, provide an appropriate mechanism for oil revenue management and amend the current Budget Act. The revised budget act will strengthen public finance management by enhancing the predictability of the budget including modalities for financing emergencies and supplementary budgets. Further and as part of the PFAA reform, the authorities have resolved to strengthen the internal commitment and control system to rein in the accumulation of expenditure arrears. To that end, they have instituted a system of submitting to Cabinet on a quarterly basis a consolidated report on unspent balances and unpaid bills. To improve cash management, the authorities intend to migrate to a treasury single account 
system for administering government finances, and request Fund TA in this regard and another one to boost capacity in managing and controlling arrears.

\section{Monetary and exchange rate policies}

12. My authorities' tightened monetary policy will be maintained in the medium term with the objective to bring down inflation to the BoU's target of 5 percent. They will remain vigilant of the inflation pressures arising from the protracted high global commodity prices and domestic supply shocks on food prices. To achieve the objective of anchoring its monetary policy on low and stable inflation, the BoU will set its CBR consistent with its disinflationary path. It will also bolster its open market operations, maintain a flexible exchange rate policy, rely substantially on foreign exchange sales for sterilization of liquidity, and in close cooperation with the Ministry of Finance will strive to improve liquidity forecasting. The BoU will continue to improve its inflation-specific analytical and forecasting tools in the context of the newly introduced ITL framework.

13. The BoU is committed to enhance the transparency of the conduct of its monetary policy also building on the new ITL framework. As part of its reform effort, the BoU has and will continue expanding its communications strategy and is developing a composite index of economic activity as part of the high frequency indicators for monetary policy analysis. The authorities have, in this regard, requested the Fund's TA. My authorities are also committed to continue promoting orderly financial markets and to strengthening the transmission channel from interest rates to domestic demand and inflation. The authorities will also endeavor to make progress in the preparation for and negotiations of the East African Monetary Union. To that end, the EAC partner states appreciate the targeted support by the Fund in key relevant areas and look forward to continued and strengthened engagement.

14. On the exchange rate, the BoU remains committed to a flexible exchange rate regime and continue to see this as the first line of defense against external shocks. The BoU will remain vigilant and only intervene occasionally to smooth out excessive volatility. The authorities will also, over the medium term, seek to accumulate a high level of international reserves from the current 3.5 months of import cover to the 6 months cover target consistent with the East African Monetary Union convergence criteria.

\section{Financial sector}

15. The BoU will continue to enhance its supervisory and regulatory services to the financial institutions to enhance the stability of the country's financial system in line with the recommendations of the recent FSAP update. Through the Uganda Retirements Benefits Act of 2011, the authorities have established a regulatory framework for the entire pension sector. They are also committed to implement further financial sector reforms, strengthen the regulatory framework for financial institutions to be fully consistent with the 2005 Basel 
Core Principles, and to update the Financial Institutions Act to allow banks to offer additional products. EAC regional integration protocols are providing the baseline framework for collaboration to reduce the risks from cross-border flows. The legislation to strengthen anti-money laundering is before Parliament.

\section{The new oil economy}

16. The authorities are mindful of the huge potential of oil revenues including the sizable capital gains taxes. They intend to ring-fence oil revenues for infrastructure investments by establishing a petroleum fund to (i) finance expenditures exclusively through the budget, and (ii) generate revenue savings for future generations. In their commitment to enhance transparency in oil revenue management, they are considering joining the Extractive Industries Initiative (EITI). To that end, the reporting requirements in the proposed amendment to the PFAA will be designed to comply with the EITI requirements.

17. To maintain balanced growth in the medium term, the authorities are determined to ensure that the new oil economy will not compromise the growth of non-oil sectors. They are aware that this will entail building capacities in managing oil resources. To that end, they appreciate the Fund's effort to provide them with comprehensive TA under the new Topical Trust Fund for Managing Natural Resources Wealth (MNRW-TTF).

\section{Conclusion}

18. The authorities' macroeconomic fundamentals and continued commitment to strong policies helped the economy restore its growth momentum faster than earlier envisaged. They are aware of the reemerging risks from the protracted global economic uncertainties and regional supply and demand shocks. They are, in this regard, prepared to take appropriate measures to protect the gains in the country's macroeconomic stability. In the near term, the authorities are determined to ensure that the program focuses on sustaining macroeconomic stability and the related fiscal consolidation path, and enhancing domestic resource mobilization, while promoting broad-based and pro-poor growth, and increasing investment in infrastructure, primary sectors and core MDG clusters. They are aware of the future opportunities and challenges arising from the new oil economy. They, therefore, request continued support from the Fund, other international financial institutions, and development partners in their efforts to strengthen macroeconomic stability, restore high growth rates with low inflation for poverty reduction and attainment of the MDGs. 